\title{
Use of Rhizosphere Microorganisms in Plant Production - A Review Study
}

\author{
Dominika Paliwoda', Grzegorz Mikiciuk ${ }^{1 *}$ \\ 1 Department of Horticulture, Faculty of Environmental Management and Agriculture, West Pomeranian \\ University of Technology in Szczecin, Słowackiego 17, 71-434 Szczecin, Poland \\ * Corresponding author's e-mail: grzegorz.mikiciuk@zut.edu.pl
}

\begin{abstract}
Minimizing or neutralizing the effects of environmental stresses on crop plants, protecting against pests and diseases, and at the same time ensuring optimal plant growth and development are currently the most important tasks faced by growers and plant producers around the world. Nowadays, the goal is to limit the use of chemicals as much as possible to protect the environment and improve the quality of food. The interest in the use of beneficial rhizosphere microorganisms is becoming global, as it can represent an environmentally friendly alternative to chemicalization in the era of threats to crop cultivation in the modern world (climate change, drought, salinity, introduction of plant pests).
\end{abstract}

Keywords: PGPM, PGPR, PGPF, AMF, environmental stresses

\section{INTRODUCTION}

The microbiome communities living in an environment affects the health of plants, people, and other living things. In plants, different microbiomes colonize in various niches, in phyllosphere, endosphere (in the tissues) and rhizosphere (Berendsen et al. 2012).

The rhizosphere is the root zone where the interactions occurring at the plant-microorganism-soil level are influenced by a number of chemical ( $\mathrm{pH}$, nutrient content, exudates), physical (temperature, water availability, soil structure), and biological (bacteria and fungi) factors (Mimmo et al. 2018).

Rhizosphere microbial communities and their interactions have been the subject of research for many years, aimed at determining their influence on plant development (Philippot et al. 2013, Berg et al. 2014). Many authors showed that microorganisms bring many benefits to cultivated plants, such as: nutrient uptake (Berendsen et al. 2012), protection against soil pathogens (Mendes et al. 2013), and resistance to environmental stresses (Pérez-Jaramillo et al. 2015). The rhizosphere is a site of microbiological activity contributed to by bacteria, fungi, protozoa, nematodes, algae, and archaea (Lakshmanan et al. 2014). Plant Growth Promoting Microorganisms (PGPM) - bacteria and fungi, including mycorrhizal fungi, are the most widely studied groups of microorganisms.

Plant Growth Promoting Microorganisms can be divided into Plant Growth Promoting Rhizobacteria - PGPR and Plant Growth Promoting Fungi - PGPF (Mishra et al. 2017).

PGPR are microorganisms essentially present in the rhizosphere and include the following strains of bacteria: Acinetobacter, Alcaligenes, Allorhizobium, Arthrobacter, Azorhizobium, Azospirillum, Bacillus, Bradyrhizobium, Burkholderia, Enterobacter, Erwinia, Flavobacterium, Frankia, Mezorhizobium, Pseudomonas, Rhizobium and Sinorhizobium (Sharma et al. 2016, Patel et al. 2016, Bashan et al. 2016, Lal et al. 2016). According to Chauhan et al. (2015), the group of Plant Growth Promoting Bacteria also includes the recently used strains, such as: Pantoea, Methylobacterium, Exiguobacterium, Paenibacillus and Azoarcus. PGPR contribute to plant growth through direct or indirect mechanisms. Any 
mechanism that protects a plant against infections (biotic stress) or helps it develop under abiotic stress is an indirect mechanism. In contrast, the direct mechanism affects the plant growth through the supply of nutrients or the production of plant growth regulators (Goswami et al. 2016).

The interaction with PGPF also proves to be extremely beneficial for the flora. Fungi of the genera such as Aspergillus, Fusarium, Penicillium, Piriformospora, Phoma and Trichoderma are the strains most used in research (Hossain et al. 2017, Javaid et al. 2019). Comparison of the results of various experiments shows that the interactions at the plant-PGPF level can have a positive effect on the aerial and underground plant organs. According to Akhtar and Javaid (2018), PGPF provide plants with protection against diseases by limiting the penetration by pathogens. Yadav et al. (2017) showed in their study that application of fungi to the soil increased nutrient availability to plants, thus increasing plant growth and crop yields.

Mycorrhizal symbiosis is the most common and widespread synergy between microorganisms and plants. As reported by Bonfante and Genre (2010), endophytic fungi (endomycorrhiza, arbuscular mycorrhiza - AM, Arbuscular Mycorrhizal Fungi-AMF) are a group of fungi of the Glomeromycota genera that form symbiotic relationships with over $90 \%$ of higher plant families. According to many authors, inoculation with AMF provides plants with tolerance to various environmental stresses such as salinity, water deficit, heavy metals in soil, and low or high temperatures.

\section{The role of rhizosphere microorganisms in alleviating environmental stresses}

Stress factors affect the growth and development of plants in agricultural and horticultural production. Light, water, and minerals are the factors regulating their growth, development and reproduction (Lata et al. 2018). However, when the access to them is disturbed, plants undergo physiological and morphological modifications to adapt to sudden changes (Shukla et al. 2012).

Abiotic stresses that affect the plant production efficiency include drought, salinity, hot and cold stress, as well as light stress. When listing the factors negatively affecting yielding, one cannot ignore the lack of nutrient availability in the soil, content of heavy metals, and the presence of plant pathogens (Lata and Gond 2019).
Plant growth under stress conditions can be enhanced by the use of stress-resistant rhizosphere microorganisms such as PGPR, PGPF and AMF (Nadeem et al. 2014). According to Spence and Bais (2015), these microorganisms enhance the plant development through, for example, regulation of the hormonal and nutritional balance, production of plant growth regulators, and induction of resistance to pathogens.

\section{The role of rhizosphere microorganisms in alleviating the drought stress}

The drought-induced stress is one of the most serious world problems, which reduces the crop production. Almost 30\% of the Earth's soils are exposed to this stress (Calvo-Polanco et al. 2016). This stress has multidimensional influence on plants, from the phenological and morphological levels down to the molecular level (Anjum et al. 2011).

According to Lata and Prasad (2011) and Naveed et al. (2014), the water deficit causes many negative changes in plants such as decrease of chlorophyll concentration, disorders of photosynthetic apparatus, inhibition of photosynthesis and transpiration, increase in ethylene production and decrease in relative water content. The limited water content causes a decrease in the size of cells in tissues, disrupts membrane integrity, inhibits production of ROS in plants, and promotes leaf senescence (Tiwari et al. 2015, Kaur and Asthir 2016).

The rhizosphere microorganisms stimulate the growth of plants during drought stress by inducing various mechanisms such as production of plant growth regulators (IAA, cytokinins and ABA), production of bacterial exopolysaccharides (EPS), and synthesis of ACC deaminase (Farooq et al. 2009, Porcel et al. 2014).

Plant Growth Promoting Rhizobacteria have the ability to produce phytohormones that stimulate cell division and plant growth under the water deficit conditions (Kumar and Verma 2018). According to Goswami et al. (2015), IAA regulates differentiation of vascular tissues, stimulates cell division, and root and shoot growth under stress. Abscisic acid (ABA) alleviates the stress caused by water deficit through transcription and regulation of xylem transport to the aerial parts of plants (Jiang et al. 2013). Vardharajula et al. (2011) claim that the bacteria Bacillus sp., counted among the PGPR, reduce antioxidant activity, 
but increase the synthesis of proline, free amino acids and production of sugars in plants.

According to Mena-Violante et al. 2006, Ruiz-Lozano et al., 2015, Yooyongwech et al. 2016 and Moradtalab et al. 2019, the mycorrhizal fungi alleviate drought stress in the cultivation of various species such as: pepper, lettuce, tomato, strawberry and sweet potato. It has been shown that symbiotic relationships with AMF can contribute to root growth, increase leaf surface area and plants biomass under water deficit (Gholamhoseini et al. 2013).

Inoculation with AMF affects the physiological characteristics of plants, e.g. stomatal conductance, leaf water potential (LWP), relative water content (RWC), and $\mathrm{CO}_{2}$ assimilation (He et al. 2017, Chandrasekaran et al. 2019). According to Ludwig-Müller (2010), MF and PGPR, induce the synthesis of abscisic acid (ABA), which under stress conditions regulates some of physiological processes, e.g. stomatal conductance. Supplementary information is shown in the Table 1 .

\section{The role of rhizosphere microorganisms in alleviating salinity stress}

Excessive soil salinity is a complex phenomenon, harmful to plants because it causes disorders of the ionic and osmotic homeostasis. It leads to a reduction in growth and development, and premature senescence of plants (Bojorquez-Quintal et al. 2014, Enebe and Babalola 2018, Julkowska and Testerink 2015). Salinity is mainly caused by $\mathrm{Na}^{+}$, $\mathrm{Ca}^{2+}, \mathrm{K}^{+}$and also $\mathrm{Cl}^{-}$and $\mathrm{NO}^{3-}$ (Shrivastava and $\mathrm{Ku}-$ mar 2015). It reduces the microbiological activity of the soil, which is caused by ion toxicity and osmotic stress, which affect the reduction in growth of plant.

There have been many studies confirming that the inoculation with rhizosphere microorganisms alleviates the negative effects of salinity on various plants. PGPM can stimulate the growth of the plants that are exposed to salinity, by direct and indirect mechanisms. Rhizosphere bacteria reduce the effects of excessive soil salinity, also by producing the so-called biofilm (biological membrane) on the roots (Kasim et al. 2016).

Both PGPR and AMF help plants adapt to salinity, increasing the availability of nutrients, improving water uptake, increasing the efficiency of $\mathrm{CO}_{2}$ assimilation, and the synthesis of osmoregulators and phytohormones (auxins, cytokinins, ethylene, gibberellins) (Hajiboland et al. 2010, Porcel et al. 2015, Hayat et al. 2010).
As reported by Choudhary et al. (2015), the PGPR that are studied in terms of their interaction with plant growth in salinity stress include Acetobacter, Azospirillum, Bacillus, Pseudomonas, Rhizobium and Serratia. Damodaran et al. (2013) demonstrated that Bacillus pumilus and Bacillus subtilis found in saline soil had tolerance to salt stress, through various mechanisms, e.g. synthesis of IAA, ACC deaminase, ammonia and hydrogen cyanide $(\mathrm{HCN})$, and by phosphate solubilization or siderophore production. Bacilio et al. (2016), showed that inoculation with bacteria Pseudomonas stutzeri reduces the negative impact of excessive soil salinity on pepper plants.

Some authors reported the effectiveness of AMF in increasing the growth and yielding of plants in salinity (Talaat and Shawky 2014, Latef and Chaoxing 2014). For some plants, coinoculation with mycorrhizal fungi (AMF) and saline-tolerant bacteria can also improve their salinity resistance. According to Krishnamoorthy et al. (2016), co-inoculation with Rhizophagus intraradices and Massilia sp. RK4 (bacteria) together with AMF (fungi) showed a significant effect on the tolerance to excessive soil salinity in maize plants. Supplementary information is shown in Table 2.

\section{The role of rhizosphere microorganisms in alleviating temperature stress (heat stress, cold stress)}

The constantly changing climate contributes to increasing the risk of temperature stress, a significant threat to the crop productivity worldwide (Kumar and Verma 2018). According to Wahid et al. (2007), Hasanuzzaman et al. (2013) and Zandalinas et al. (2018), heat stress significantly affects the biochemical and physiological traits of plants, development, growth and yielding (causing loss of vigour and inhibition of seed germination, smaller plant mass, wilting and leaf senescence, fruit damage and discoloration, as well as cell apoptosis and increased oxidative stress). At heat stress, plants accumulate antioxidants (ascorbate peroxidase, catalase), osmoprotectants, and Heat Shock Proteins (HSP) - HSP20, HSP 60, HSP70, HSP 90, HSP100 (Bokszczanin 2013, Qu et al. 2013, Kotak et al. 2007).

Zhuang et al. (2019), reported that the stress associated with low temperature affects a lot of biological processes, such as a damage to cell membranes and changes in the photosynthetic 
Table 1. Responses of plants in water deficit to inoculation of different rhizosphere microorganisms

\begin{tabular}{|c|c|c|c|}
\hline Microorganism & Plant species & Effect & Research author \\
\hline \multicolumn{4}{|c|}{ Plant Growth Promoting Rhizobacteria (PGPR) } \\
\hline $\begin{array}{l}\text { Pseudomonas libanensis TR1 } \\
\text { Pseudomonas reactans Ph3R3 }\end{array}$ & $\begin{array}{c}\text { Brassica oxyrrhina } \\
\text { Coss. }\end{array}$ & $\begin{array}{l}\text { plant growth, increase in leaf } \\
\text { water content (LWC), increase } \\
\text { in chlorophyll content }\end{array}$ & Ma et al. 2016a \\
\hline $\begin{array}{c}\text { Proteus penneri } \mathrm{Pp} 1 \\
\text { Pseudomonas aeruginosa (Pa2) } \\
\text { Alcaligenes faecalis (AF3) }\end{array}$ & $\begin{array}{c}\text { maize } \\
\text { (Zea mays L.) }\end{array}$ & $\begin{array}{l}\text { increase in relative water } \\
\text { content (RWC), increase in } \\
\text { protein and sugar content, } \\
\text { increase in proline content }\end{array}$ & $\begin{array}{c}\text { Naseem and Bano } \\
2014\end{array}$ \\
\hline Trichoderma longibrachiatum & $\begin{array}{l}\text { wheat } \\
\text { (Triticum aestivum L.) }\end{array}$ & $\begin{array}{c}\text { increase in relative water } \\
\text { content (RWC), increase in } \\
\text { chlorophyll and proline content }\end{array}$ & Zhang et. al. 2016 \\
\hline Azospirillum brasilense Sp 245 & $\begin{array}{l}\text { thale cress } \\
\text { (Arabidopsis thaliana } \\
\text { (L.) Heynh.) }\end{array}$ & $\begin{array}{l}\text { increase in plant yielding, } \\
\text { increase in relative water } \\
\text { content (RWC), increase in } \\
\text { proline content }\end{array}$ & Cohen et. al. 2015 \\
\hline $\begin{array}{c}\text { Pseudomonas entomophila BV-P13 } \\
\text { Pseudomonas stutzeri GRFHAP-P14 } \\
\text { Pseudomonas putida GAP-P45 } \\
\text { Pseudomonas syringae GRFHYTP5 } \\
\text { Pseudomonas monteilli WAPP53 }\end{array}$ & $\begin{array}{c}\text { maize } \\
\text { (Zea mays L.) }\end{array}$ & $\begin{array}{l}\text { increase in proline, sugars and } \\
\text { free amino acids content }\end{array}$ & $\begin{array}{c}\text { Vardharajula et al. } \\
2010\end{array}$ \\
\hline $\begin{array}{l}\text { Bacillus cereus AR156 } \\
\text { Bacillus subtilis SM21 } \\
\text { Serratia sp. XY21 }\end{array}$ & $\begin{array}{c}\text { cucumber } \\
\text { (Cucumis sativus L.) }\end{array}$ & $\begin{array}{l}\text { activation of Induced Systemic } \\
\text { Resistance (ISR), maintain } \\
\text { photosyntetic performance, } \\
\text { vigour and antioxidant activity }\end{array}$ & Wang et al. 2012 \\
\hline Pseudomonas aeruginosa GGRJ21 & $\begin{array}{l}\text { mung bean } \\
\text { (Vigna radiata L.) }\end{array}$ & $\begin{array}{l}\text { production of reactive oxygen } \\
\text { species (ROS), increase in } \\
\text { relative water content (RWC), } \\
\text { increase in shoots, roots and } \\
\text { dry matter }\end{array}$ & $\begin{array}{l}\text { Sarma and Saikia } \\
2014\end{array}$ \\
\hline \multicolumn{4}{|c|}{ Plant Growth Promoting Fungi (PGPF) } \\
\hline Trichoderma atroviride ID20G & $\begin{array}{c}\text { maize } \\
\text { (Zea mays L.) }\end{array}$ & $\begin{array}{l}\text { increase in fresh and dry root } \\
\text { mass, increase in chlorophyll } \\
\text { and carotenoid content, } \\
\text { inhibition of lipid peroxidation, } \\
\text { induction of antioxidant } \\
\text { enzymes, decrease in hydrogen } \\
\text { superoxide }\left(\mathrm{H}_{2} \mathrm{O}_{2}\right) \text { content } \\
\end{array}$ & Guler et al. 2016 \\
\hline Exophiala sp. LHL08 & $\begin{array}{c}\text { cucumber } \\
\text { (Cucumis sativus L.) }\end{array}$ & $\begin{array}{c}\text { abscisic acid (ABA), salicylic } \\
\text { acid (SA) and gibberellin (GA) } \\
\text { induction }\end{array}$ & Khan et al. 2011a \\
\hline \multicolumn{4}{|c|}{ Arbuscular Mycorrhizal Fungi (AMF) } \\
\hline $\begin{array}{l}\text { Rhizophagus irregularis } \\
\text { Glomus intraradices }\end{array}$ & $\begin{array}{c}\text { lettuce } \\
\text { (Lactuca sativa L.), } \\
\text { tomato (Lycopersicon } \\
\text { esculentum Mill.) }\end{array}$ & $\begin{array}{c}\text { plant growth, indole-3-acetic } \\
\text { acid production, increase } \\
\text { in Photosystem II (PSII) } \\
\text { performance }\end{array}$ & $\begin{array}{l}\text { Ruiz-Lozano et al. } \\
2015\end{array}$ \\
\hline $\begin{array}{l}\text { Acaulospora sp. } \\
\text { Glomus sp. }\end{array}$ & $\begin{array}{l}\text { sweet potato } \\
\text { (Ipomoea batatas (L.) } \\
\text { Poir) }\end{array}$ & $\begin{array}{c}\text { increase in efficiency of } \\
\text { Photosystem II (PSII), increase } \\
\text { in chlorophyll, proline and } \\
\text { sugars content }\end{array}$ & $\begin{array}{c}\text { Yooyongwech et al. } \\
2016\end{array}$ \\
\hline Rhizophagus clarus & $\begin{array}{l}\text { strawberry (Fragaria } \\
\text { ananassa Duch.) }\end{array}$ & $\begin{array}{c}\text { increase in dry matter, increase } \\
\text { in relative water content (RWC), } \\
\text { maintenance of antioxidant } \\
\text { activity }\end{array}$ & $\begin{array}{l}\text { Moradtalab et al. } \\
2019\end{array}$ \\
\hline $\begin{array}{l}\text { Glomus etunicatum } \\
\text { Glomus microaggregatum } \\
\text { Glomus intraradices } \\
\text { Glomus claroideum } \\
\text { Glomus mosseae } \\
\text { Glomus geosporum }\end{array}$ & $\begin{array}{c}\text { olive } \\
\text { (Olea europaea L.) }\end{array}$ & $\begin{array}{l}\text { increase in relative water } \\
\text { content (RWC), increase in } \\
\text { turgor pressure, increase in } \\
\text { proline content }\end{array}$ & Sara et al. 2018 \\
\hline Rhizophagus intraradices & $\begin{array}{c}\text { maize } \\
\text { (Zea mays L.) }\end{array}$ & $\begin{array}{l}\text { increase in dry matter andwater } \\
\text { use efficiency photosynthesis } \\
\text { (WUE) }\end{array}$ & Zhao et al. 2015 \\
\hline
\end{tabular}


Table 2. Responses of plants in salinity stress to inoculation of different rhizosphere microorganisms

\begin{tabular}{|c|c|c|c|}
\hline Microorganism & Plant species & Effect & Research author \\
\hline \multicolumn{4}{|c|}{ Plant Growth Promoting Rhizobacteria (PGPR) } \\
\hline Pseudomonas fluorescens & $\begin{array}{l}\text { pistachio tree } \\
\text { (Pistacia L.) }\end{array}$ & $\begin{array}{l}\text { deaminase ACC synthesis, } \\
\text { production of indole-3- } \\
\text { acetic acid (IAA), phosphate } \\
\text { solubilization, siderophore } \\
\text { production }\end{array}$ & Azarmi et al. 2015 \\
\hline $\begin{array}{l}\text { Acinetobacter spp. } \\
\text { Pseudomonas sp. }\end{array}$ & $\begin{array}{c}\text { barley } \\
\text { (Hordeum vulgare } \mathrm{L}) \\
\text { oat } \\
\text { (Avena sativa } \mathrm{L})\end{array}$ & $\begin{array}{l}\text { deaminase ACC and indole- } \\
\text { 3-acetic acid (IAA) synthesis, } \\
\text { reducing ethylene production }\end{array}$ & Chang et al. 2014 \\
\hline Hartmannibacter diazotrophicus E19 & $\begin{array}{c}\text { barley } \\
\text { (Hordeum vulgare L.) }\end{array}$ & $\begin{array}{l}\text { increase in dry matter, } \\
\text { deaminase ACC synthesis, } \\
\text { reducing ethylene production }\end{array}$ & Suarez et al. 2015 \\
\hline Pseudomonas putida UW4 & $\begin{array}{c}\text { rapeseed } \\
\text { (Brassica napus L.) }\end{array}$ & $\begin{array}{l}\text { synthesis of ACC deaminase } \\
\text { enzyme, modulation of gene } \\
\text { expression }\end{array}$ & Cheng et al. 2011 \\
\hline $\begin{array}{c}\text { Haererohalobacter JG-11 } \\
\text { Brachybacterium saurashtrense JG-06 } \\
\text { Brevibacterium casei JG-08 }\end{array}$ & $\begin{array}{c}\text { peanut } \\
\text { (Arachis hypogaea L.) }\end{array}$ & $\begin{array}{c}\text { production of abscisic acid } \\
(\mathrm{ABA}) \text {, increased availability of } \\
\text { nitrogen }(\mathrm{N}) \text {, phosphorus }(\mathrm{P}), \\
\text { higher calcium cations }(\mathrm{Ca} 2+) \\
\text { and higher potassium }(\mathrm{K}+) \text { to } \\
\text { sodium }(\mathrm{Na}+) \text { ratio }\end{array}$ & Shukla et al. 2012 \\
\hline \multicolumn{4}{|c|}{ Plant Growth Promoting Fungi (PGPF) } \\
\hline Piriformospora indica & $\begin{array}{c}\text { aloe } \\
\text { (Aloe vera (L.) Burm. f.) }\end{array}$ & $\begin{array}{l}\text { root growth, increase in } \\
\text { chlorophyll and flavonoid } \\
\text { content }\end{array}$ & Sharma et al. 2016 \\
\hline Cochliobolus sp. & $\begin{array}{c}\text { okra } \\
\text { (Ablemoschus } \\
\text { esculentus (L.) Moench) }\end{array}$ & $\begin{array}{c}\text { plant growth, increase in dry } \\
\text { matter, increase in chlorophyll, } \\
\text { carotenoids and xanthophylls, } \\
\text { increase in relative water } \\
\text { content (RWC), increase in soil } \\
\text { salinity tolerance with sodium } \\
\text { chloride }(\mathrm{NaCl}) \\
\end{array}$ & Bibi et al. 2019 \\
\hline \multicolumn{4}{|c|}{ Arbuscular Mycorrhizal Fungi (AMF) } \\
\hline Glomus deserticola & $\begin{array}{c}\text { basil } \\
\text { (Ocimum basilicum L.) }\end{array}$ & $\begin{array}{c}\text { reduction of absorption of } \\
\text { potassium }(\mathrm{K}+) \text {, phosphorus } \\
(\mathrm{P}+) \text { and calcium }(\mathrm{Ca} 2+) \\
\text { cations, improved } \\
\text { photosynthesis and gas } \\
\text { exchange efficiency, increase } \\
\text { of chlorophyll content, increase } \\
\text { of water use efficiency in } \\
\text { photosynthesis (WUE) }\end{array}$ & Elhindi et al. 2017 \\
\hline Glomus fasciculatum & $\begin{array}{c}\text { garlic } \\
\text { (Allium sativum L.) }\end{array}$ & $\begin{array}{c}\text { increase in dry matter, } \\
\text { increase in photosynthesis } \\
\text { and phosphatase activity by } \\
\text { increasing nutrient availability }\end{array}$ & Borde et al. 2010 \\
\hline $\begin{array}{l}\text { Glomus mosseae } \\
\text { Glomus intraradices }\end{array}$ & $\begin{array}{c}\text { pepper } \\
\text { (Capsicum annuum L.) }\end{array}$ & $\begin{array}{c}\text { increase in relative water } \\
\text { content (RWC), increase in } \\
\text { chlorophyll and carotenoids } \\
\text { content }\end{array}$ & Çekiç et al. 2012 \\
\hline
\end{tabular}

apparatus and starch metabolism in plant cells. The rhizosphere microorganisms induce the processes by which plants are able to inhibit or eliminate the effects of cold stress. These processes include: production of ACC deaminase to minimize the synthesis of ethylene caused by low temperature, increased the nitrogen fixation processes for the plants exposed to frost, synthesis of plant growth regulators (ABA, GA, IAA), activation of antioxidant enzymes, release of iron chelators (siderophores), and increasing the nutrients uptake (Kushwaha et al. 2020).

According to Turan et al. (2013), the inoculation with PGPR such as Azospirillum brasilense, Bacillus megaterium, Bacillus subtilis and Raoultella terrigena minimized the adverse effects of low temperature on barley and wheat seedlings. 
Table 3. Responses of plants in temperature stress to inoculation of different rhizosphere microorganisms

\begin{tabular}{|c|c|c|c|}
\hline Microorganism & Plant species & Effect & Research author \\
\hline \multicolumn{4}{|c|}{ HEAT STRESS (HS) } \\
\hline \multicolumn{4}{|c|}{ Plant Growth Promoting Rhizobacteria (PGPR) } \\
\hline Pseudomonas lurida M2RH3 & $\begin{array}{c}\text { wheat } \\
\text { (Triticum aestivum L.) }\end{array}$ & $\begin{array}{l}\text { phosphate solubilization, } \\
\text { indole-3-acetic acid production, } \\
\text { siderophores production }\end{array}$ & $\begin{array}{l}\text { Selvakumar et al. } \\
2011\end{array}$ \\
\hline Pseudomonas aeruginosa 2CpS1 & $\begin{array}{c}\text { wheat } \\
\text { (Triticum aestivum L.) }\end{array}$ & $\begin{array}{c}\text { plant growth, root growth, leaf area } \\
\text { index (LAI), increase in chlorophylls } \\
\text { content, increase in relative water } \\
\text { content (RWC), decrease in cell } \\
\text { membrane damage }\end{array}$ & Meena et al. 2015 \\
\hline Brevibacterium linens RS1 & $\begin{array}{c}\text { eucalypt } \\
\text { (Eucalyptus grandis) }\end{array}$ & $\begin{array}{c}\text { increase in efficiency of the } \\
\text { Photosystem II (PSII), increase } \\
\text { in } \mathrm{CO}_{2} \text { assimilation, increase in } \\
\text { stomatal conductance }\end{array}$ & $\begin{array}{l}\text { Chatterjee et al. } \\
\qquad 2019\end{array}$ \\
\hline Bacillus tequilensis SSB07 & $\begin{array}{c}\text { soybean } \\
\text { (Glycine max (L.) } \\
\text { Merr.) }\end{array}$ & $\begin{array}{l}\text { shoot growth development of } \\
\text { leaves, increase in chlorophyll } \\
\text { and carotenoids content, increase } \\
\text { in salicylic and jasmonic acid } \\
\text { synthesis in the phylosphere }\end{array}$ & Kang et al. 2020 \\
\hline \multicolumn{4}{|c|}{ Plant Growth Promoting Fungi (PGPF) } \\
\hline Thermomyces sp. & $\begin{array}{c}\text { cucumber } \\
\text { (Cucumis sativus L.) }\end{array}$ & $\begin{array}{c}\text { root growth, maintaining the } \\
\text { efficiency of the Photosystem } \\
\text { II (PSII), increase in water use } \\
\text { efficiency (WUE), increase in sugar } \\
\text { and protein content }\end{array}$ & Ali et al. 2018 \\
\hline \multicolumn{4}{|c|}{ Arbuscular Mycorrhizal Fungi (AMF) } \\
\hline Glomus intraradices & $\begin{array}{c}\text { asparagus (Asparagus } \\
\text { officinalis L.) }\end{array}$ & $\begin{array}{c}\text { shoot growth, increase in root dry } \\
\text { matter, increased availability of } \\
\text { nitrogen }(\mathrm{N}), \text { phosphorus }(\mathrm{P}) \text { and } \\
\text { potassium }(\mathrm{K}), \text { increased activity of } \\
\text { antioxidant enzymes (superoxide } \\
\text { dismutase, ascorbate peroxidase) } \\
\end{array}$ & Yeasmin et al. 2019 \\
\hline $\begin{array}{l}\text { Rhizophagus intraradices } \\
\text { Funneliformis mosseae } \\
\text { Funneliformis geosporum }\end{array}$ & $\begin{array}{c}\text { maize } \\
\text { (Zea mays L.) }\end{array}$ & $\begin{array}{c}\text { plant growth (shoots, leaves, } \\
\text { inflorescences, root system), higher } \\
\text { chlorophyll content, maintaining } \\
\text { photosynthetic activity }\end{array}$ & Mathur et al. 2018 \\
\hline $\begin{array}{c}\text { Rhizophagus irregularis BEG140 } \\
\text { Rhizophagus irregularis } \\
\text { Funneliformis mosseae BEG95 } \\
\text { Funneliformis geosporum } \\
\text { Claroideoglomus claroideum }\end{array}$ & $\begin{array}{c}\text { wheat } \\
\text { (Triticum aestivum L.) }\end{array}$ & $\begin{array}{l}\text { plant growth, higher number } \\
\text { of grains per spike, increased } \\
\text { availability of macro- and } \\
\text { microelements, increase in } \\
\text { efficiency of the Photosystem II } \\
\text { (PSII) }\end{array}$ & Cabral et al. 2016 \\
\hline \multicolumn{4}{|c|}{ COLD STRESS (CS) } \\
\hline \multicolumn{4}{|c|}{ Plant Growth Promoting Rhizobacteria (PGPR) } \\
\hline $\begin{array}{l}\text { Bacillus spp. CJCL2 } \\
\text { Bacillus ssp. RJGP41 }\end{array}$ & $\begin{array}{c}\text { wheat } \\
\text { (Triticum aestivum L.) }\end{array}$ & $\begin{array}{l}\text { increase in proline content, } \\
\text { inhibition of lipid peroxidation }\end{array}$ & Zubair et al. 2019 \\
\hline \multicolumn{4}{|c|}{ Arbuscular Mycorrhizal Fungi (AMF) } \\
\hline Glomus etunicatum & $\begin{array}{c}\text { maize } \\
\text { (Zea mays L.) }\end{array}$ & $\begin{array}{c}\text { increase in chlorophyll a, b and total } \\
\text { chlorophyll content, increase in PS } \\
\text { II and photosynthetic efficiency, } \\
\text { higher transpiration, increase in } \\
\text { stomatal conductance }\end{array}$ & Zhu et al. $2010 b$ \\
\hline Glomus mosseae & $\begin{array}{l}\text { tomato } \\
\text { (Lycopersicon } \\
\text { esculentum Mill.) }\end{array}$ & $\begin{array}{c}\text { increase in superoxide dismutase, } \\
\text { catalase and ascorbate peroxidase } \\
\text { activity, increase in assimilation } \\
\text { pigments, sugars and proteins } \\
\text { content }\end{array}$ & $\begin{array}{l}\text { Latef i Chaoxing } \\
\qquad 2011\end{array}$ \\
\hline Rhizophagus intraradices & $\begin{array}{c}\text { purging nut (Jatropha } \\
\text { curcas L.) }\end{array}$ & $\begin{array}{l}\text { increase in catalase and glutathione } \\
\text { peroxidase activity }\end{array}$ & $\begin{array}{l}\text { Pedranzani et al. } \\
2015\end{array}$ \\
\hline
\end{tabular}


Zhu et al. (2010b), Abdel Latef and Chaoxing (2011b), Birhane et al. (2012), Chen et al. (2013) and Liu et al. (2013) stated in their reports that inoculation with AMF increase plant resistance to cold. Supplementary information is shown in the Table 3.

\section{The role of rhizosphere microorganisms in increasing the availability of nutrients in the soil}

Nutrient deficiency, even at an asymptomatic level, is an important factor reducing the plants crop (Jewell et al. 2010, Etesami and Adl 2020).

Inoculation with microorganisms such as PGPR and PGPF can affect the availability of nutrients for plants (Zhang et al. 2014, Ma et al. 2015, Damodharan et al. 2018). The processes by which rhizosphere microorganisms directly facilitate the uptake of nutrients or increase their availability include: atmospheric nitrogen fixation, solubilization of sparingly soluble phosphorus and potassium, and synthesis of siderophores (Bhattacharyya and Jha 2012, Hayat et al. 2012, Rana et al. 2012 and Di Salvo et al. 2018).

Atmospheric nitrogen fixation is a process proceeding both non-symbiotic and symbiotic interactions between microorganisms and plants (Sridhar 2012). The nitrogen-fixing microorganisms help to increase the absorption capacity of plants. Roots release exudates, which are processed by bacteria, which then provide plants with assimilable nitrogen for the synthesis of amino acids (Lata et al. 2018). As reported by Kuan et al. (2016), Rhizobium, Pantoea agglomerans, Azoarcus and Klebsiella pneumoniae are a group of bacteria that are the most suitable for atmospheric nitrogen fixation in the soil. The rhizosphere microorganisms secrete some organic acids (citric acid, apple acid, succinic acid), which solubilize the phosphorus forms unavailable to plants and transform them into an assimilable inorganic form (Waghunde et al. 2017). Among the types of rhizosphere bacteria, Oteino et al. (2015) distinguish those that promote the process of solubilization (increasing solubility), which include: Arthrobacter, Bacillus, Pseudomonas, Rhizobium, Burkholderia, Flavobacterium, Rhodococcus and Serratia. Liu et al. (2012) claim that such rhizosphere bacteria as Acidothiobacillus, Bacillus, Paenibacillus and Pseudomonas release potassium from potassium compounds into the soil in a form available to plants. Pseudomonas putida produce the iron chelating compounds, i.e. siderophores, and bind them to the rhizosphere, making them available to plants (Rathore 2015). Supplementary information is shown in the Table 4 .

\section{The role of rhizosphere microorganisms in the detoxification of heavy metals in the soil}

Accumulation of heavy metals is an environmental problem that negatively affect human health, plants, and the soil (Singh et al. 2019). These elements, do not degrade, and are also toxic at low concentrations (Ma et al. 2016a, Ma et al. 2016b).

The interactions of heavy metals with bacteria increase their bioavailability, which can lead to their detoxification or removal from the soil (Mishra et al. 2017). The use of PGPR is a practical, environmentally friendly, and at the same time economical approach to alleviating the stress associated with the high concentration of heavy metals in soil (Upadhyay et al. 2011, Ahemad 2014). Khan and Bano (2016) and Karthik et al. (2017) declared that PGPR increase plant tolerance to heavy metals and reduce their toxicity. According to Khan et al. (2018), PGPR also promote the process of phytoremediation.

As reported by Zhang et al. (2015), bacteria such as: Proteobacteria, Firmicutes and Actinobacteria, eliminate high concentrations of manganese $(\mathrm{Mn})$, lead $(\mathrm{Pb})$ and arsenic (As) from soils. Jing et al. (2014), reported that the bacteria of the Enterobacter and Klebsiella genera are effective against cadmium, lead and zinc in the soil, through the production of phytohormones (IAA), siderophores, and ACC deaminase synthesis.

According to Kanwal et al. (2015) and Miransari (2017), mycorrhizal fungi, when exerting a positive effect on plant in stress, increase nutrient uptake and biomass production, while reducing the toxicity of metals in plants. Supplementary information is shown in the Table 5 .

\section{The role of rhizosphere microorganisms in increasing physiological activity, plant growth and yielding}

Hossain et al. (2017) as well as Smith and Read (2008) reported the benefits of the interaction of plants with rhizosphere microorganisms, which include: improved germination, better root and shoot development and growth, 
Table 4. Responses of plants in availability of nutrients in the soil to inoculation of different rhizosphere microorganisms

\begin{tabular}{|c|c|c|c|}
\hline Microorganism & Plant species & Effect & Research author \\
\hline \multicolumn{4}{|c|}{ Plant Growth Promoting Rhizobacteria (PGPR) } \\
\hline $\begin{array}{c}\text { Bacillus M-3 } \\
\text { Bacillus OSU-142 } \\
\text { Pseudomonas BA-8 }\end{array}$ & $\begin{array}{c}\text { strawberry } \\
\text { (Fragaria ananassa } \\
\text { Duch.) }\end{array}$ & $\begin{array}{l}\text { increase the availability of } \\
\text { phosphorus }(P) \text {, iron }(\mathrm{Fe}) \text {, } \\
\text { zinc }(\mathrm{Zn}) \text {, potassium }(\mathrm{K}) \text { and } \\
\text { magnesium }(\mathrm{Mg})\end{array}$ & Esitken et al. 2010 \\
\hline $\begin{array}{c}\text { Pseudomonas aeruginosa BHUJY16 } \\
\text { Pseudomonas aeruginosa BHUJY20 } \\
\text { Pseudomonas putida BHUJY13 } \\
\text { Pseudomonas putida BHUJY23 } \\
\text { Pseudomonas fluorescens BHUJY29 } \\
\text { Azotobacter chroococcum } \\
\text { Azospirillum brasilense } \\
\end{array}$ & $\begin{array}{c}\text { rice } \\
\text { (Oryza sativa L.) }\end{array}$ & $\begin{array}{c}\text { increase the availability of } \\
\text { nitrogen }(N) \text { and phosphorus }(P)\end{array}$ & $\begin{array}{l}\text { Lavakush et al. } \\
\qquad 2014\end{array}$ \\
\hline $\begin{array}{c}\text { Bacillus M3 } \\
\text { Bacillus OSU-142 } \\
\text { Microbacterium FS01 }\end{array}$ & $\begin{array}{c}\text { apple } \\
\text { (Malus domestica } \\
\text { Borkh.) 'Granny Smith' }\end{array}$ & $\begin{array}{c}\text { increase the availability of } \\
\text { nitrogen }(\mathrm{N}), \mathrm{P} \text { (phosphorus), } \\
\text { Ca (calcium), potassium }(\mathrm{K}), \\
\text { zinc }(\mathrm{Zn}), \text { iron (Fe), manganese } \\
(\mathrm{Mn}) \\
\end{array}$ & Karlidag et al. 2007 \\
\hline $\begin{array}{l}\text { Bacillus cereus } \\
\text { Pseudomonas sp. }\end{array}$ & $\begin{array}{c}\text { tomato } \\
\text { (Lycopersicon } \\
\text { esculentum Mill.) }\end{array}$ & $\begin{array}{l}\text { increase the availability of } \\
\text { potassium }(\mathrm{K})\end{array}$ & Etesami et al. 2017 \\
\hline \multirow{2}{*}{$\begin{array}{c}\text { Bacillus amyloliquefaciens IN937a } \\
\text { Bacillus pumilus T4 }\end{array}$} & \multirow{2}{*}{$\begin{array}{l}\text { tomato (Lycopersicon } \\
\text { esculentum Mill.) }\end{array}$} & $\begin{array}{l}\text { increase in nitrogen }(\mathrm{N}) \\
\text { availability, phosphate } \\
\text { solubilization }\end{array}$ & Fan et al. 2017 \\
\hline & & $\begin{array}{l}\text { increase in nitrogen }(\mathrm{N}) \\
\text { availability }\end{array}$ & $\begin{array}{l}\text { Adesemoye et al. } \\
2010\end{array}$ \\
\hline Bacillus amyloliquefaciens L-S60 & $\begin{array}{c}\text { cucumber } \\
\text { (Cucumis sativus L.) }\end{array}$ & $\begin{array}{l}\text { increase the availability of } \\
\text { nitrogen }(N) \text {, phosphorus }(P) \\
\text { and potassium (K) }\end{array}$ & Qin et al. 2017 \\
\hline $\begin{array}{l}\text { Pseudomonas chlororaphis } \\
\text { Pseudomonas putida }\end{array}$ & $\begin{array}{c}\text { soybean } \\
\text { (Glycine max (L.) } \\
\text { Merr.) }\end{array}$ & phosphate solubilization & Gouda et al. 2018 \\
\hline \multicolumn{4}{|c|}{ Plant Growth Promoting Fungi (PGPF) } \\
\hline $\begin{array}{l}\text { Aspergillus tubingensis PSF-4 } \\
\text { Aspergillus niger PSF-7 }\end{array}$ & $\begin{array}{c}\text { maize } \\
\text { (Zea mays L.), } \\
\text { wheat } \\
\text { (Triticum aestivum } \text { L.) }\end{array}$ & phosphate solubilization & Kaur i Reddy 2016 \\
\hline Aspergillus niger NCIM 563 & $\begin{array}{c}\text { wheat } \\
\text { (Triticum aestivum L.) }\end{array}$ & phosphate solubilization & Gujar et al. 2013 \\
\hline \multicolumn{4}{|c|}{ Arbuscular Mycorrhizal Fungi (AMF) } \\
\hline Rhizophagus irregularis & $\begin{array}{c}\text { barrelclover } \\
\text { (Medicago truncatula } \\
\text { Gaertn.) }\end{array}$ & $\begin{array}{l}\text { phosphate and zinc } \\
\text { solubilization }\end{array}$ & Nguyen et al. 2019 \\
\hline $\begin{array}{l}\text { Glomus mosseae } \\
\text { Glomus intraradices }\end{array}$ & $\begin{array}{c}\text { pistachio tree } \\
\text { (Pistacia vera L. cv. } \\
\text { Qazvini, } \\
\text { Pistacia vera L. cv. } \\
\text { Badami-Riz-Zarand) }\end{array}$ & $\begin{array}{c}\text { increase the availability of } \\
\text { phosphorus }(P) \text {, potassium }(K) \\
\text { zinc }(\mathrm{Zn}) \text { and manganese }(\mathrm{Mn})\end{array}$ & Bagheri et al. 2012 \\
\hline
\end{tabular}

morphogenesis, positive impact on flowering, higher photosynthetic rate, and yielding.

PGPR and AMF increase the absorptive surface of roots and nutrients uptake (Leifheit et al. 2015, Sas-Paszt et al. 2011). They can also indirectly affect the intensity of photosynthesis by increasing the stomatal conductance to $\mathrm{CO}_{2}$ and the efficiency of photochemical reactions. They increase the quantity and quality of yield, especially in the plants growing in stress (Khade and Rodrigues 2009, Karlidag et al. 2013). Seema et al. (2018) demonstrated that the application of Bacillus promotes the assimilation and transpiration in the leaves of strawberry. According to Chen et al. (2017), some of the mycorrhizal fungi genera (Claroideoglomus, Diversispora, Funneliformis, Rhizophagus) increase the stomatal conductance and the rate of photosynthesis, in cucumber plants.

According to Hossain et al. (2017), the genera of PGPF such as: Alternaria, Aspergillus, Cladosporium, Colletotrichum, Exophiala, Fusarium, Penicillium, Phoma, Phomopsis, Rhizoctonia, 
Table 5. Responses of plants exposed to heavy metal accumulation in the soil to inoculation with different rhizosphere microorganisms

\begin{tabular}{|c|c|c|c|}
\hline Microorganism & Plant species & Effect & Research author \\
\hline \multicolumn{4}{|c|}{ Plant Growth Promoting Rhizobacteria (PGPR) } \\
\hline $\begin{array}{c}\text { Bacillus cereus } \\
\text { Pseudomonas moraviensis }\end{array}$ & $\begin{array}{c}\text { wheat } \\
\text { (Triticum aestivum L.) }\end{array}$ & $\begin{array}{l}\text { reduction of cadmium }(\mathrm{Cd}) \text {, } \\
\text { cobalt }(\mathrm{Co}) \text {, chromium }(\mathrm{Cr}), \\
\text { copper }(\mathrm{Cu}) \text { and manganese } \\
(\mathrm{Mn}) \text { in the soil }\end{array}$ & Hassan et al. 2016 \\
\hline $\begin{array}{c}\text { Planomicrobium chinense P1 } \\
\text { Bacillus cereus P2 }\end{array}$ & $\begin{array}{c}\text { sunflower (Helianthus } \\
\text { annus L.) }\end{array}$ & $\begin{array}{l}\text { reduction of cadmium }(\mathrm{Cd}) \text {, lead } \\
(\mathrm{Pb}) \text { and nickel }(\mathrm{Ni}) \text { in the soil }\end{array}$ & Khan et al. 2018 \\
\hline $\begin{array}{c}\text { Rhizobium leguminosarum (M5) } \\
\text { Bacillus simplex } \\
\text { Luteibacter sp. } \\
\text { Variovorax sp. }\end{array}$ & \multirow{2}{*}{$\begin{array}{c}\text { grass pea } \\
\text { (Lathyrus sativus L.) }\end{array}$} & \multirow{2}{*}{$\begin{array}{l}\text { reduction of cadmium }(\mathrm{Cd}) \text { and } \\
\text { lead }(\mathrm{Pb}) \text { in the soil }\end{array}$} & \multirow{2}{*}{$\begin{array}{l}\text { Abdelkrim et al. } \\
\qquad 2020\end{array}$} \\
\hline $\begin{array}{c}\text { Rhizobium leguminosarum (M5) } \\
\text { Pseudomonas fluorescens (K23) } \\
\text { Luteibacter sp. } \\
\text { Variovorax sp. }\end{array}$ & & & \\
\hline Bacillus thuringiensis GDB-1 & $\begin{array}{l}\text { Alnus firma Siebold } \\
\text { \& Zucc }\end{array}$ & $\begin{array}{l}\text { reduction of arsenic }(\mathrm{As}) \text {, lead } \\
(\mathrm{Pb}), \text { nickel }(\mathrm{Ni}) \text {, zinc }(\mathrm{Zn}) \\
\text { copper }(\mathrm{Cu}) \text { in the soil }\end{array}$ & Babu et al. 2013 \\
\hline $\begin{array}{l}\text { Thiobacillus thiooxidans } \\
\text { Pseudomonas putida }\end{array}$ & $\begin{array}{c}\text { gladiolus, sword lily } \\
\text { (Gladiolus grandiflorus } \\
\text { L.) }\end{array}$ & $\begin{array}{l}\text { reduction of cadmium }(\mathrm{Cd}) \text { and } \\
\text { lead }(\mathrm{Pb}) \text { in the soil }\end{array}$ & Mani et al. 2016 \\
\hline Bradyrhizobium japonicum & $\begin{array}{c}\text { lettuce } \\
\text { (Lactuca sativa L.) }\end{array}$ & $\begin{array}{c}\text { reduction of copper }(\mathrm{Cu}) \text { and } \\
\text { nickel }(\mathrm{Ni}) \text { in the soil }\end{array}$ & $\begin{array}{c}\text { Seneviratne et al. } \\
2016 \\
\end{array}$ \\
\hline Bacillus pumilus E2S2 & $\begin{array}{c}\text { Sedum } \\
\text { plumbizincicola } \\
\text { X.H.Guo \& S.B.Zhou } \\
\text { ex L.H.Wu } \\
\end{array}$ & $\begin{array}{l}\text { reduction of cadmium }(\mathrm{Cd}) \text { and } \\
\text { zinc }(\mathrm{Zn}) \text { in the soil }\end{array}$ & Ma et al. 2015 \\
\hline \multicolumn{4}{|c|}{ Arbuscular Mycorrhizal Fungi (AMF) } \\
\hline Glomus mosseae BEG167 & $\begin{array}{c}\text { maize } \\
\text { (Zea mays L.) }\end{array}$ & $\begin{array}{l}\text { increase tolerance to cadmium } \\
(\mathrm{Cd}) \text { and zinc }(\mathrm{Zn}) \text { in plants }\end{array}$ & Shen et al. 2006 \\
\hline $\begin{array}{l}\text { Glomus etunicatum } \\
\text { Glomus macrocarpum } \\
\text { Gigaspora margarita }\end{array}$ & $\begin{array}{c}\text { Moluccan albizia } \\
\text { (Falcataria moluccana } \\
\text { Miq.) }\end{array}$ & $\begin{array}{c}\text { lower soil pH, plant growth } \\
\text { (shoots, roots), increase in dry } \\
\text { matter, increase in soil organic } \\
\text { carbon }(\mathrm{C}), \text { reduction in soil } \\
\text { copper }(\mathrm{Cu})\end{array}$ & Rollon et al. 2017 \\
\hline \multirow{2}{*}{ Glomus intraradices } & $\begin{array}{c}\text { tobacco } \\
\text { (Nicotiana tabacum } \\
\text { L.) }\end{array}$ & $\begin{array}{l}\text { de-accumulation of cadmium } \\
\text { (Cd) in the soil }\end{array}$ & $\begin{array}{l}\text { Janoušková and } \\
\text { Pavlíková } 2010\end{array}$ \\
\hline & $\begin{array}{c}\text { alfalfa } \\
\text { (Medicago sativa L.) }\end{array}$ & $\begin{array}{l}\text { de-accumulation of cadmium } \\
(\mathrm{Cd}) \text { in the soil }\end{array}$ & Wang et al. 2012 \\
\hline
\end{tabular}

Trichoderma, contribute to the acceleration of plant growth. Chirino-Valle et al. (2016) found the impact of inoculation with Trichoderma fungi on the growth of the giant miscanthus (Miscanthus $\times$ giganteus). According to Vázquez-de-Aldana et al. (2013), Hossain et al. (2014) and Islam et al. (2014b), many PGPF genera also stimulate root system development. Supplementary information is shown in the Table 6.

\section{The role of rhizosphere microorganisms in pathogen elimination}

According to Etesami and Maheshwari (2018), Berendsen et al. (2012) and also Pieterse et al. (2014) PGPR, PGPF and AMF can protect plants against pathogenic microorganisms by activation systemic resistance in plants (ISR). ISR can be induced by fungi PGPF such as Fusarium, Penicillium, Phythophthora, Pythium, Trichoderma and also AMF such as Funneliformis, Glomus, and Rhizophagus (Bent 2006). Induction of this resistance eliminates the harmful effects of bacteria, fungi, viruses and nematodes on plants (Fontenelle et al. 2011, Elsharkawy et al. 2012, Hossain and Sultana 2015, Vu et al. 2006). Lee et al. (2015), in their study on the induction of ISR in ginseng infected with Phytophthora cactorum, showed that inoculation with Bacillus amyloliquefaciens HK34 induced ISR. Supplementary information is shown in the Table 7. 
Table 6. The role of different rhizosphere microorganisms in physiological activity, plant growth and yielding

\begin{tabular}{|c|c|c|c|}
\hline Microorganism & Plant species & Effect & Research author \\
\hline \multicolumn{4}{|c|}{ Plant Growth Promoting Rhizobacteria (PGPR) } \\
\hline $\begin{array}{c}\text { Bacillus M3 } \\
\text { Bacillus OSU-142 } \\
\text { Microbacterium FS01 }\end{array}$ & \begin{tabular}{|c|} 
apple \\
(Malus domestica \\
Borkh.) 'Granny Smith'
\end{tabular} & $\begin{array}{c}\text { increase in yield, increase in fruit } \\
\text { weight, increase in shoot length } \\
\text { and thickness }\end{array}$ & Karlidag et al. 2007 \\
\hline Bacillus amyloliquefaciens IT45 & $\begin{array}{c}\text { strawberry } \\
\text { (Fragaria ananassa } \\
\text { Duch.) }\end{array}$ & $\begin{array}{c}\text { increase chlorophyll a and total } \\
\text { chlorophylls, rate of transpiration } \\
\text { and } \mathrm{CO}_{2} \text { concentration in the } \\
\text { intercellular spaces in the } \\
\text { leaves, increase chlorophyll } \\
\text { fluorescence }\end{array}$ & $\begin{array}{l}\text { Mikiciuk et al. } \\
2019 \mathrm{~b}\end{array}$ \\
\hline $\begin{array}{c}\text { Pseudomonas putida R-168 } \\
\text { Pseudomonas fluorescens R-93 } \\
\text { Pseudomonas fluorescens DSM } 50090 \\
\text { Pseudomonas putida DSM291 } \\
\text { Azospirillum lipoferum DSM } 1691 \\
\text { Azospirillum brasilense DSM } 1690\end{array}$ & $\begin{array}{c}\text { maize } \\
\text { (Zea mays L.) }\end{array}$ & $\begin{array}{l}\text { better seed germination, dry } \\
\text { matter and plant growth }\end{array}$ & Gholami et al. 2009 \\
\hline $\begin{array}{l}\text { Azospirillum spp. } \\
\text { Azoarcus spp. } \\
\text { Azorhizobium spp. }\end{array}$ & $\begin{array}{c}\text { wheat } \\
\text { (Triticum aestivum L.) }\end{array}$ & $\begin{array}{l}\text { increase in the root system, } \\
\text { increase in nitrogen }(\mathrm{N}) \\
\text { availability for plants }\end{array}$ & $\begin{array}{l}\text { Dal Cortivo et al. } \\
2017\end{array}$ \\
\hline \multicolumn{4}{|c|}{ Plant Growth Promoting Fungi (PGPF) } \\
\hline Trichoderma atroviride & $\begin{array}{l}\text { Giant Miscanthus } \\
\text { (Miscanthus } \times \\
\text { giganteus) }\end{array}$ & higher shoot length & $\begin{array}{l}\text { Chirino-Valle et al. } \\
2016\end{array}$ \\
\hline Cladosporium sp. MH-6 & $\begin{array}{c}\text { Suaeda japonica } \\
\text { Makino }\end{array}$ & $\begin{array}{l}\text { increase in shoot length, fresh } \\
\text { and dry matter }\end{array}$ & $\begin{array}{l}\text { Hamayun et al. } \\
2010\end{array}$ \\
\hline Epichloë festucae & $\begin{array}{c}\text { red fescue } \\
\text { (Festuca rubra L.) }\end{array}$ & increase in root mass & $\begin{array}{c}\text { Vázquez-de-Aldana } \\
\text { et al. } 2013\end{array}$ \\
\hline Penicillium viridicatum GP15-1 & $\begin{array}{c}\text { cucumber } \\
\text { (Cucumis sativus L.) }\end{array}$ & $\begin{array}{l}\text { greater root fresh mass and root } \\
\text { dry mass, higher root length }\end{array}$ & Hossain et al. 2014 \\
\hline Fusarium spp. PPF1 & $\begin{array}{l}\text { Malabar spinach, } \\
\text { Indian spinach } \\
\text { (Basella alba L.) }\end{array}$ & $\begin{array}{l}\text { greater root fresh mass and root } \\
\text { dry mass, higher root length }\end{array}$ & Islam et al. 2014b \\
\hline $\begin{array}{c}\text { Penicillium expansum } \\
\text { Penicillium bilaii } \\
\text { Penicillium implicatum } \\
\text { Penicillium oxalicum } \\
\text { Penicillium verrucosum } \\
\text { Penicillium simplicissimum } \\
\text { Penicillium citrinum }\end{array}$ & $\begin{array}{c}\text { tomato } \\
\text { (Lycopersicon } \\
\text { esculentum Mill.) }\end{array}$ & $\begin{array}{l}\text { better seed germination, plant } \\
\text { growth (shoot and root system) }\end{array}$ & Mushtaq et al. 2012 \\
\hline $\begin{array}{c}\text { Penicillium chrysogenum } \\
\text { Phoma sp. } \\
\text { Trichoderma koningi }\end{array}$ & \begin{tabular}{|c|} 
opuntia \\
(Opuntia streptacantha \\
Lem.)
\end{tabular} & seed dormancy interruption & $\begin{array}{l}\text { Delgado-Sanchez } \\
\quad \text { et al. } 2011\end{array}$ \\
\hline $\begin{array}{l}\text { Penicillium chrysogenum } \\
\text { Penicillium aurantiogriseum } \\
\text { Saccharomyces cerevisiae }\end{array}$ & $\begin{array}{l}\text { thale cress } \\
\text { (Arabidopsis thaliana } \\
\text { (L.) Heynh.) }\end{array}$ & flowering induction & $\begin{array}{l}\text { Sánchez-López et } \\
\text { al. } 2016\end{array}$ \\
\hline Pirimorfospora indica & $\begin{array}{c}\text { Indian Coleus (Coleus } \\
\text { forskohlii Briq) }\end{array}$ & $\begin{array}{l}\text { speeding up flowering, increase } \\
\text { flowering intensity }\end{array}$ & Das et al. 2012 \\
\hline $\begin{array}{c}\text { Trichoderma harzianum T-3 } \\
\text { Rhizoctonia solani RS10 }\end{array}$ & $\begin{array}{c}\text { pea } \\
\text { (Pisum sativum L.) }\end{array}$ & increase yielding & Akhter et al. 2015 \\
\hline Pochonia chlamydosporia & $\begin{array}{c}\begin{array}{c}\text { tomato (Lycopersicon } \\
\text { esculentum Mill.) }\end{array} \\
\end{array}$ & higher fruit numer and weight & $\begin{array}{c}\text { Zavala-Gonzalez et } \\
\text { al. } 2015 \\
\end{array}$ \\
\hline \multicolumn{4}{|c|}{ Arbuscular Mycorrhizal Fungi (AMF) } \\
\hline $\begin{array}{l}\text { Rhizophagus irregularis } \\
\text { Glomus mosseae } \\
\text { Claroideoglomus etunicatum }\end{array}$ & $\begin{array}{c}\text { grapevine } \\
\text { (Vitis vinifera L.) } \\
\text { 'Pinot Noir', 'Regent', } \\
\text { 'Rondo' }\end{array}$ & $\begin{array}{c}\text { increase in } \mathrm{CO}_{2} \text { assimilation, } \\
\text { transpiration and stomatal } \\
\text { conductance }\end{array}$ & Mikiciuk et al. 2019a \\
\hline Rhizophagus irregularis CD1 & $\begin{array}{c}\text { cotton } \\
\text { (Gossypium hirsutum } \\
\text { L.) }\end{array}$ & $\begin{array}{c}\text { increase yielding, improving fruit } \\
\text { quality }\end{array}$ & Gao et al. 2020 \\
\hline $\begin{array}{l}\text { Rhizophagus irregularis, } \\
\text { Funneliformis mosseae, } \\
\text { Claroideoglomus etunicatum } \\
\text { Rhizophagus intraradices }\end{array}$ & $\begin{array}{l}\text { strawberry (Fragaria } \\
\text { ananassa Duch.) }\end{array}$ & $\begin{array}{l}\text { increase chlorophyll a and } \\
\text { total chlorophylls, rate } \\
\text { of transpiration and } \mathrm{CO}_{2} \\
\text { concentration in the intercellular } \\
\text { spaces in the leaves, increase } \\
\text { chlorophyll fluorescence }\end{array}$ & Mikiciuk et al. 2019b \\
\hline
\end{tabular}


Table 7. Responses of plants exposed to pathogens to inoculation with different rhizosphere microorganisms

\begin{tabular}{|c|c|c|c|c|}
\hline Microorganism & Plant species & Pathogen & Effect & $\begin{array}{l}\text { Research } \\
\text { author }\end{array}$ \\
\hline \multicolumn{5}{|c|}{ Plant Growth Promoting Rhizobacteria (PGPR) } \\
\hline Paenibacillus P16 & $\begin{array}{c}\text { cabbage } \\
\text { (Brassica oleracea } \\
\text { var. capitata L.) }\end{array}$ & $\begin{array}{c}\text { Xanthomonas campestris } \\
\text { pv. campestris (Xcc) }\end{array}$ & $\begin{array}{c}\text { reduce severity of } \\
\text { black rot in cabbage. }\end{array}$ & $\begin{array}{l}\text { Ghazalibiglar } \\
\text { et al. } 2016\end{array}$ \\
\hline Brevibacterium iodinum KUDC1716 & \begin{tabular}{|c|} 
pepper \\
(Capsicum annuum \\
L.) \\
\end{tabular} & Stemphylium lycopersici & $\begin{array}{l}\text { reduce severity of } \\
\text { gray leaf spot in } \\
\text { pepper }\end{array}$ & $\begin{array}{l}\text { Son et al. } \\
2014\end{array}$ \\
\hline $\begin{array}{c}\text { Bacillus pumilus INR7 } \\
\text { Bacillus pumilus SE34 } \\
\text { Bacillus pumilus T4 } \\
\text { Bacillus amyloliquefaciens IN937a } \\
\text { Bacillus subtilis IN937b } \\
\text { Bacillus subtilis GB03 } \\
\text { Brevibacillus brevis IPC11 }\end{array}$ & $\begin{array}{c}\text { rice } \\
\text { (Oryza sativa L.) }\end{array}$ & $\begin{array}{c}\text { Xanthomonas oryzae pv. } \\
\text { oryzae (Xoo) }\end{array}$ & $\begin{array}{l}\text { reduce severity of } \\
\text { bacterial leaf blight } \\
\text { in rice }\end{array}$ & $\begin{array}{l}\text { Chithrashree } \\
\text { et al. } 2011\end{array}$ \\
\hline Bacillus amyloliquefaciens HK34 & $\begin{array}{l}\text { ginseng } \\
\text { (Panax ginseng } \\
\text { C.A. Meyer) }\end{array}$ & Phytophthora cactorum & $\begin{array}{c}\text { identification of } \\
\text { marker genes } \\
\text { (PgPR5, PgPR10 } \\
\text { i PgCAT), induction } \\
\text { of ISR }\end{array}$ & Lee et al. 2015 \\
\hline \multicolumn{5}{|c|}{ Plant Growth Promoting Fungi (PGPF) } \\
\hline \multirow{3}{*}{ Meyerozyma guilliermondii TA-2 } & $\begin{array}{c}\text { cabbage } \\
\text { (Brassica oleracea } \\
\text { var. capitata L.) }\end{array}$ & Alternaria brassicicola & $\begin{array}{l}\text { reduce severity of } \\
\text { black rot in cabbage }\end{array}$ & \multirow{3}{*}{$\begin{array}{l}\text { Elsharkawy et } \\
\text { al. } 2015\end{array}$} \\
\hline & $\begin{array}{c}\text { tomato } \\
\text { (Lycopersicon } \\
\text { esculentum Mill.) }\end{array}$ & Ralstonia solanacearum & $\begin{array}{l}\text { reduce severity of } \\
\text { tomato bacterial wilt }\end{array}$ & \\
\hline & $\begin{array}{c}\text { rice } \\
\text { (Oryza sativa L.) }\end{array}$ & Magnaporthe oryzae & $\begin{array}{l}\text { reduce severity of } \\
\text { rice blast }\end{array}$ & \\
\hline Fusarium spp. UPM31P1 & $\begin{array}{c}\text { tomato } \\
\text { (Lycopersicon } \\
\text { esculentum Mill.) }\end{array}$ & $\begin{array}{l}\text { Fusarium oxysporum } \\
\text { f. sp. cubense race } 4\end{array}$ & $\begin{array}{l}\text { reduce severity } \\
\text { of fusarium wilt in } \\
\text { tomato }\end{array}$ & $\begin{array}{l}\text { Ting et al. } \\
2010\end{array}$ \\
\hline Penicillium sp. GP15-1 & $\begin{array}{c}\text { cucumber (Cucumis } \\
\text { sativus L.) }\end{array}$ & Colletotrichum orbiculare & $\begin{array}{c}\text { reduction number of } \\
\text { lesions (anthracnose) } \\
\text { on leaves }\end{array}$ & $\begin{array}{l}\text { Hossain et al. } \\
2014\end{array}$ \\
\hline $\begin{array}{l}\text { Ampelomyces sp. } \\
\text { Cladosporium sp. }\end{array}$ & $\begin{array}{c}\text { thale cress } \\
\text { (Arabidopsis } \\
\text { thaliana (L.) } \\
\text { Heynh.) }\end{array}$ & $\begin{array}{l}\text { Pseudomonas syringae } \\
\text { pv. tomato DC } 3000\end{array}$ & $\begin{array}{c}\text { reduce severity of } \\
\text { bacterial speck of } \\
\text { tomato, pathogen } \\
\text { proliferation }\end{array}$ & $\begin{array}{l}\text { Naznin et al. } \\
\quad 2014\end{array}$ \\
\hline Talaromyces wortmannii FS2 & $\begin{array}{c}\text { komatsuna, } \\
\text { mustard spinach } \\
\text { (Brassica } \\
\text { campestris var. } \\
\text { perviridis) } \\
\end{array}$ & $\begin{array}{l}\text { Colletotrichum } \\
\text { higginsianum }\end{array}$ & $\begin{array}{c}\text { produce } \\
\beta \text {-caryophyllene, } \\
\text { enhance resistance/ } \\
\text { tolerance }\end{array}$ & $\begin{array}{l}\text { Yamagiwa et } \\
\text { al. } 2011\end{array}$ \\
\hline \multicolumn{5}{|c|}{ Arbuscular Mycorrhizal Fungi (AMF) } \\
\hline $\begin{array}{l}\text { Funneliformis mosseae } \\
\text { Rhizophagus irregularis }\end{array}$ & $\begin{array}{c}\text { paradise apple } \\
\text { (Malus pumila Mill.) }\end{array}$ & Neonectria ditissima & $\begin{array}{c}\text { increase resistance } \\
\text { to Neonectria } \\
\text { ditissima }\end{array}$ & $\begin{array}{l}\text { Berdeni et al. } \\
\quad 2018\end{array}$ \\
\hline
\end{tabular}

\section{CONCLUSIONS}

The plant growth promoting microorganisms are important to the rhizosphere and can improve the growth and development of plants. PGPM can support the human activity in protecting plants from stress factors in agricultural and horticultural crops. Furthermore, they contribute to the availability of nutrients and protection against soil pathogens, and have an significant role in phytoremediation and soil fertility improvement. This issue is extremely important and requires further research on the possibilities of using microorganisms in global plant production in different ecosystems. The extension of the research should be based on a thorough analysis of the plant-microorganism-stress factor-soil interactions. Understanding the interrelationships between these factors is important for improving the rational application of PGPM in plant crops. 


\section{REFERENCES}

1. Abdelkrim, S., Jebara, S.H., Saadani, O., Abid, G., Taamalli, W., Zemni, H., Jebara, M. 2020. In situ effects of Lathyrus sativus - PGPR to remediate and restore quality and fertility of $\mathrm{Pb}$ and $\mathrm{Cd}$ polluted soils. Ecotoxicol Environ Saf, 192, 110260. doi:10.1016/j.ecoenv.2020.110260.

2. Abdel Latef A.A., Chaoxing H. 2011b. Arbuscular mycorrhizal influence on growth, photosynthetic pigments, osmotic adjustment and oxidative stress in tomato plants subjected to low temperature stress. Acta Physiol. Plant., 33, 1217-1225.

3. Adesemoye A.O., Torbert H.A., Kloepper J.W. 2010. Increased plant uptake of nitrogen from $15 \mathrm{~N}$ depleted fertilizer using Plant Growth-Promoting Rhizobacteria. Appl. Soil Ecol., 46(1), 54-58.

4. Ahemad M. 2014. Phosphate solubilizing bacteriaassisted phytoremediation of metalliferous soils: a review. Biotech, 5(2), 111-121.

5. Akhtar R., Javaid A. 2018. Biological management of basal rot of onion by Trichoderma harzianum and Withania somnifera. Planta Daninha, 35, 1-7.

6. Akhter W., Bhuiyan M.K.A., Sultana F., Hossain M.M. 2015. Integrated effect of microbial antagonist, organic amendment and fungicide in controlling seedling mortality (Rhizoctonia solani) and improving yield in pea (Pisum sativum L.). C. R. Biol, 338, 21-28.

7. Ali A.H., Abdelrahman M., Radwan U., El-Zayat S., El-Sayed M.A. 2018. Effect of Thermomyces fungal endophyte isolated from extreme hot desert-adapted plant on heat stress tolerance of cucumber. Appl. Soil Ecol., 124, 155-162.

8. Anjum S.A., Xie X-Y., Wang L-C., Saleem M.F., Man C., Lei W. 2011. Morphological, physiological and biochemical responses of plants to drought stress. Afr. J. Agric. Res., 6(9), 2026-2032.

9. Azarmi F., Mozafari V., Abbaszadeh Dahaji P., Hamidpour M. 2015. Biochemical, physiological and antioxidant enzymatic activity responses of pistachio seedlings treated with plant growth promoting rhizobacteria and $\mathrm{Zn}$ to salinity stress. Acta Physiol Plant, 38(21), 1-16.

10. Babu A.G., Kim J-D., Oh B-T. 2013. Enhancement of heavy metal phytoremediation by Alnus firma with endophytic Bacillus thuringiensis GDB-1. J. Hazard. Mater., 250-251, 477-483.

11. Bacilio M., Moreno M., Bashan Y. 2016. Mitigation of negative effects of progressive soil salinity gradients by application of humic acids and inoculation with Pseudomonas stutzeri in a salt-tolerant and a saltsusceptible pepper. Appl. Soil. Ecol., 107, 394-404.

12. Bagheri V., Shamshiri M.H., Shirani H., Roosta H.R. 2012. Nutrient Uptake and Distribution in Mycorrhizal Pistachio Seedlings under Drought Stress.
J. Agr. Sci. Tech., 14, 1591-1604.

13. Bashan Y., de-Bashan L.E., Prabhu S.R. 2016. Superior Polymeric Formulations and Emerging Innovative Products of Bacterial Inoculants for Sustainable Agriculture and the Environment. In: Singh, H., Sarma, B., Keswani, C. (eds) Agriculturally Important Microorganisms. Springer, Singapore, 15-46.

14. Bent E. 2006. Induced systemic resistance mediated by plant growth-promoting rhizobacteria (PGPR) and Fungi (PGPF). In: Tuzun S, Bent E (eds) Multigenic and induced systemic resistance in plants. Springer, New York, 225-258.

15. Berdeni D., Cotton T.E.A., Daniell T.J., Bidartondo M.I., Cameron D.D., Evans K.L. 2018. The Effects of Arbuscular Mycorrhizal Fungal Colonisation on Nutrient Status, Growth, Productivity and Canker Resistance of Apple (Malus pumila). Front Microbiol, 9(1461), 1-14.

16. Berendsen R.L., Pieterse C.M.J., Bakker P.A.H.M. 2012. The rhizosphere microbiome and plant health. Trends Plant Sci, 17(8), 478-486.

17. Berg G., Grube M., Schloter M., Smalla K. 2014. Unraveling the plant microbiome: looking back and future perspectives. Front Microbiol, 5, 1-7.

18. Bhattacharyya P.N., Jha D.K. 2011. Plant growthpromoting rhizobacteria (PGPR): emergence in agriculture. World J. Microbiol. Biotechnol., 28(4), 1327-1350.

19. Bibi N., Jan G., Jan F.G., Hamayun M., Iqbal A., Hussain A., Rehman H., Tawab A., Khushdil F. 2019. Cochliobolus sp. acts as a biochemical modulator to alleviate salinity stress in okra plants. Plant Physiol. Biochem., 139, 459-469.

20. Birhane E., Sterck F., Fetene M., Bongers F., Kuyper T. 2012. Arbuscular mycorrhizal fungi enhance photosynthesis, water use efficiency and growth of frankincense seedlings under pulsed water availability conditions. Oecologia, 169, 895-904.

21. Bojorquez-Quintal J., Velarde A., Ku A., CarilloPech M., Ortega-Camacho D., Echevarría-Machado I., Pottosin I., Martínez-Estévez M. 2014. Mechanisms of salt tolerance in habanero pepper plants (Capsicum chinense Jacq.): proline accumulation, ions dynamics, root-shoot partition and compartmentation. Front. Plant Sci, 5, 605. doi: 10.3389/ fpls.2014.00605.

22. Bokszczanin K.L. 2013. Perspectives on deciphering mechanisms underlying plant heat stress response and thermotolerance. Front. Plant Sci, 4, 315. doi: 10.3389/fpls.2013.00315.

23. Bonfante P., Genre A. 2010. Mechanisms underlying beneficial plant-fungus interactions in mycorrhizal symbiosis. Nat Commun, 1, 48. doi: 10.1038/ ncomms 1046.

24. Borde M., Dudhane M., Jite P.K. 2010. AM fungi influences the photosynthetic activity, growth and 
antioxidant enzymes in Allium sativum L. under salinity condition. Not. Sci. Biol., 2, 64-71.

25. Cabral C., Ravnskov S., Tringovska I., Wollenweber B. 2016. Arbuscular mycorrhizal fungi modify nutrient allocation and composition in wheat (Triticum aestivum L.) subjected to heat-stress. Plant Soil, 408(1-2), 385-399.

26. Calvo-Polanco M., Sánchez-Romera B., Aroca R., Asins M.J., Declerck S., Dodd I.C., MartínezAndújar C., Albacete A., Ruiz-Lozano J.M. 2016. Exploring the use of recombinant inbred lines in combination with beneficial microbial inoculants (AM fungus and PGPR) to improve drought stress tolerance in tomato. Environ Exp Bot, 131, 47-57.

27. Chandrasekaran M., Chanratana M., Kim K., Seshadri S., Sa T. 2019. Impact of arbuscular mycorrhizal fungi on photosynthesis, water status, and gas exchange of plants under salt stress - a metaanalysis. Front. Plant Sci., 10, 457. doi: 10.3389/ fpls.2019.00457.

28. Chang P., Gerhardt K.E., Huang X.-D., Yu X.-M., Glick B.R., Gerwing P.D., Greenberg B.M. 2014. Plant Growth-Promoting Bacteria Facilitate the Growth of Barley and Oats in Salt-Impacted Soil: Implications for Phytoremediation of Saline Soils. Int J Phytoremediat, 16(11), 1133-1147.

29. Chauhan H., Bagyaraj D.J., Selvakumar G., Sundaram S.P. 2015. Novel plant growth promoting Rhizobacteria - Prospects and potential. Appl. Soil Ecol., 95, 38-53.

30. Chatterjee P., Kanagendran A., Samaddar S., Pazouki L., Sa T-M., Niinemets Ü. 2019. Influence of Brevibacterium linens RS16 on foliage photosynthetic and volatile emission characteristics upon heat stress in Eucalyptus grandis. Sci Total Environ, 700, 134453. doi:10.1016/j.scitotenv.2019.134453.

31. Chen S., Zhao H., Zou C., Li Y., Chen Y., Wang Z., JiangY., Zhao P., Wang M., Ahammed G.J. 2017. Combined inoculation with multiple arbuscular mycorrhizal fungi improves growth, nutrient uptake and photosynthesis in cucumber seedling. Front Microbiol, 8(2516), 1-11.

32. Chen S., Jin W., Liu A., Zhang S., Liu D., Wang F., Lin X., Zhang S., He C. 2013. Arbuscular mycorrhizal fungi (AMF) increase growth and secondary metabolism in cucumber subjected to low temperature stress. Sci. Hort., 160, 222-229.

33. Cheng Z., Woody O.Z., McConkey B.J., Glick B.R. 2012. Combined effects of the plant growthpromoting bacterium Pseudomonas putida UW4 and salinity stress on the Brassica napus proteome. Appl. Soil Ecol., 61, 255-263.

34. Çekiç F.O., Unyayar S., Ortas I. 2012. Effects of arbuscular mycorrhizal inoculation on biochemical parameters in Capsicum annuum grown under long term salt stress. Turk. J. Bot., 36, 63-72.
35. Chithrashree, Udayashankar A.C., Chandra Nayaka S., Reddy M.S., Srinivas C. 2011. Plant growthpromoting rhizobacteria mediate induced systemic resistance in rice against bacterial leaf blight caused by Xanthomonas oryzae pv. oryzae. Biol Control, 59(2), 114-122.

36. Chirino-Valle I., Kandula D., Littlejohn C., Hill R., Walker M., Shields M., Cummings N., Hettiarachchi D., Wratten S. 2016. Potential of the beneficial fungus Trichoderma to enhance ecosystem-service provision in the biofuel grass Miscanthus $\times$ giganteus in agriculture. Sci Rep, 6, 25109. doi: 10.1038/srep25109.

37. Choudhary D.K, Kasotia A, Jain S., Vaishnav A, Kumari S., Sharma K.P, Varma A. 2015. Bacterialmediated tolerance and resistance to plants under abiotic and biotic stresses. J Plant Growth Regul, 35, 276-300.

38. Cohen A.C., Bottini R., Pontin M., Berli F.J., Moreno D., Boccanlandro H., Travaglia C.N., Piccoli P.N. 2014. Azospirillum brasilense ameliorates the response of Arabidopsis thaliana to drought mainly via enhancement of ABA levels. Physiol. Plant., 153(1), 79-90.

39. Dal Cortivo, C., Barion, G., Visioli, G., Mattarozzi, M., Mosca, G., Vamerali, T. 2017. Increased root growth and nitrogen accumulation in common wheat following PGPR inoculation: Assessment of plant-microbe interactions by ESEM. Agric Ecosyst Environ, 247, 396-408.

40. Damodharan K., Palaniyandi S.A., Le B., Suh J.W., Yang S.H. 2018. Streptomyces sp. strain SK68, isolated from peanut rhizosphere, promotes growth and alleviates salt stress in tomato (Solanum lycopersicum cv. Micro-Tom). J. Microbiol., 56, 753-759.

41. Das A., Kamas S., Akhtar N.S. 2012. The root endophyte fungus Piriformospora indica leads to early flowering, higher biomass and altered secondary metabolites of the medicinal plant Coleus forskohlii. Plant Signal Behav, 7, 1-10.

42. Delgado-Sánchez P., Ortega-Amaro M.A., JiménezBremont J.F., Flores J. 2011. Are fungi important for breaking seed dormancy in desert species? Experimental evidence in Opuntia streptacantha (Cactaceae). Plant Biol, 13, 154-159.

43. Di Salvo L.P., Cellucci G.C., Carlino M.E., de Salamone I.E.G. 2018. Plant growth-promoting rhizobacteria inoculation and nitrogen fertilization increase maize (Zea mays L.) grain yield and modified rhizosphere microbial communities. Appl. Soil Ecol., 126, 113-120.

44. Elhindi K.M., El-Din S.A., Elgorban A. M. 2017. The impact of arbuscular mycorrhizal fungi in mitigating salt-induced adverse effects in sweet basil (Ocimum basilicum L.). Saudi J. Biol. Sci., 24, 170-179.

45. Elsharkawy M.M., Shivanna M.B, Meera M.S, Hyakumachi M. 2015. Mechanism of induced systemic 
resistance against anthracnose disease in cucumber by plant growth-promoting fungi. Acta Agric Scand Sect B Soil Plant Sci, 65(4), 287-299

46. Elsharkawy M.M, Shimizu M., Takahashi H., Hyakumachi M. 2012. Induction of systemic resistance against Cucumber mosaic virus by Penicillium simplicissimum GP17-2 in Arabidopsis and Tobacco. Plant Pathol, 61, 964-976.

47. Enebe M.C., Babalola O.O. 2018. The influence of plant growth-promoting rhizobacteria in plant tolerance to abiotic stress: a survival strategy. Appl Microbiol Biotechnol, 102(18), 7821-7835.

48. Esitken A., Yildiz H. E., Ercisli S., Figen Donmez M., Turan M., Gunes A. 2010. Effects of plant growth promoting bacteria (PGPB) on yield, growth and nutrient contents of organically grown strawberry. Sci Hortic, 124(1), 62-66.

49. Etesami H., Maheshwari D.K. 2018. Use of plant growth promoting rhizobacteria (PGPRs) with multiple plant growth promoting traits in stress agriculture: Action mechanisms and future prospects. Ecotoxicol Environ Saf, 156, 225-246.

50. Etesami H., Emami S.E., Alikhani H.A. 2017. Potassium solubilizing bacteria (KSB): mechanisms, promotion of plant growth, and future prospects - a review. J Soil Sci Plant Nutr, 17, 897-911.

51. Etesami H., Adl S.M. 2020. Plant Growth-Promoting Rhizobacteria (PGPR) and Their Action Mechanisms in Availability of Nutrients to Plants. In: Kumar, M., Kumar, V., Prasad, R. (eds.). PhytoMicrobiome in Stress Regulation. Environmental and Microbial Biotechnology.

52. Fan X., Zhang S., Mo X., Li Y., Fu Y., Liu Z. 2017. Effects of Plant Growth-Promoting Rhizobacteria and N Source on Plant Growth and N and P Uptake by Tomato Grown on Calcareous Soils. Pedosphere, 27(6), 1027-1036.

53. Farooq M., Wahid A., Kobayashi N., Fujita D., Basra S.M.A. 2009. Plant Drought Stress: Effects, Mechanisms and Management. J Sustain Agr, 153-188.

54. Fontenelle A.D.B., Guzzo S.D., Lucon C.M.M., Harakaya R. 2011. Growth promotion and induction of resistance in tomato plant against Xanthomonas euvesicatoria and Alternaria solani by Trichoderma spp. Crop Prot, 30, 1492-1500.

55. Gao X., Guo H., Zhang Q., Guo H., Zhang L., Zhang C., Gou Z., Liu Y., Wei J., Chen A., Chu Z., Zeng F. 2020. Arbuscular mycorrhizal fungi (AMF) enhanced the growth, yield, fiber quality and phosphorus regulation in upland cotton (Gossypium hirsutum L.). Sci Rep, 10, 2084. doi: 10.1038/s41598-020-59180-3

56. Ghazalibiglar H., Hampton J.G., van Zijll de Jong E., Holyoake A. 2016. Is induced systemic resistance the mechanism for control of black rot in Brassica oleracea by a Paenibacillus sp.? Biol Control 92, 195-201.
57. Gholami A., Shahsavani S., Nezarat S. 2009. The effect of plant growth promoting rhizobacteria (PGPR) on germination, seedling growth and yield of maize. International Journal of Agricultural and Biosystems Engineering 3(1), 9-14.

58. Gholamhoseini M., Ghalavand A., Dolatabadian A., Jamshidi E., Khodaei-Joghan A. 2013. Effects of arbuscular mycorrhizal inoculation on growth, yield, nutrient uptake and irrigation water productivity of sunflowers grown under drought stress. Agric. Water Manag., 117, 106-114.

59. Goswami D., Thakker J.N. Dhandhukia P.C., Moral M.T. 2016. Portraying mechanics of plant growth promoting rhizobacteria (PGPR): A review. Cogent Food Agric, 2(1), 1127500.

60. Goswami D., Thakker J.N., Dhandhukia P.C. 2015. Simultaneous detection and quantification of indole3-acetic acid (IAA) and indole-3-butyric acid (IBA) produced by rhizobacteria from l-tryptophan (Trp) using HPTLC. J. Microbiol. Methods, 110, 7-14.

61. Gouda S., Kerry R.G., Das G., Paramithiotis S., Shin H.S., Patra J.K. 2018. Revitalization of plant growth promoting rhizobacteria for sustainable development in agriculture. Microbiol Res, 206, 131-140.

62. Gujar P.D., Bhavsar K.P., Khire J.M. 2013. Effect of phytase from Aspergillus niger on plant growth and mineral assimilation in wheat (Triticum aestivum Linn.) and its potential for use as a soil amendment. J Sci Food Agric, 93, 2242-2247.

63. Guler N.S, Pehlivan N., Karaoglu S.A. 2016. Trichoderma atroviride ID20G inoculation ameliorates drought stress-induced damages by improving antioxidant defence in maize seedlings. Acta Physiol Plant, 38, 132. https://doi.org/10.1007/ s11738-016-2153-3.

64. Hassan T.U., Bano A., Naz I. 2016. Alleviation of heavy metals toxicity by the application of plant growth promoting rhizobacteria and effects on wheat grown in saline sodic field. Int J Phytoremediat, 19(6), 522-529.

65. Hasanuzzaman M., Nahar K., Alam M., Roychowdhury R., Fujita M. 2013. Physiological, Biochemical and Molecular Mechanisms of Heat Stress Tolerance in Plants. Int. J. Mol. Sci. 14(5), 9643-9684.

66. Hajiboland R., Aliasgharzadeh N., Laiegh S.F., Poschenrieder C. 2010. Colonization with arbuscular mycorrhizal fungi improves salinity tolerance of tomato (Solanum lycopersicum L.) plants. Plant Soil 331, 313-327.

67. Hamayun M., Khan S.A., Khan A.L., Tang D-S., Hussain J., Ahmad B., Anwar Y., Lee I-J. 2010. Growth promotion of cucumber by pure cultures of gibberellin - producing Phoma sp. GAH7. World J Microbiol Biotechnol 26, 889-894.

68. Hayat R., Ahmed I., Sheirdil R.A. 2012. An Overview of Plant Growth Promoting Rhizobacteria (PGPR) 
for Sustainable Agriculture. In: Ashraf M., Öztürk M., Ahmad M., Aksoy A. (eds) Crop Production for Agricultural Improvement. Springer, Dordrecht.

69. He F., Sheng M., Tang M. 2017. Effects of Rhizophagus irregularis on photosynthesis and antioxidative enzymatic system in Robinia pseudoacacia L. under drought stress. Front. Plant Sci., 8, 183. doi: 10.3389/fpls.2017.00183.

70. Hossain M.M., Sultana F., Islam S. 2017. Plant Growth-Promoting Fungi (PGPF): Phytostimulation and Induced Systemic Resistance. In: Singh D., Singh H., Prabha R. (eds) Plant-Microbe Interactions in Agro-Ecological Perspectives. Springer, Singapore, 135-191.

71. Hossain M.M., Sultana F. 2015. Genetic variation for induced and basal resistance against leaf pathogen Pseudomonas syringae pv. tomato DC3000 among Arabidopsis thaliana accessions. Springer Plus 4, 296.

72. Hossain M.M., Sultana F., Miyazawa M., Hyakumachi M. 2014. The plant growth promoting fungi Penicillium spp. GP15-1 enhances growth and confers protection against damping-off and anthracnose in the cucumber. J Oleo Sci, 63(4), 391-400.

73. Islam S., Akanda A.M., Prova A., Sultana F., Hossain M.M. 2014b. Growth promotion effect of $F u$ sarium spp. PPF1 from Bermuda grass (Cynodon dactylon) rhizosphere on Indian spinach (Basella alba) seedlings are linked to root colonization. Arch Phytopathol Plant Protect, 47, 2319-2331.

74. Janouškova M., Pavlíková D. 2010. Cadmium immobilization in the rhizosphere of arbuscular mycorrhizal plants by the fungal extraradical mycelium. Plant Soil, 332, 511-520.

75. Javaid A., Afzal R., Shoaib A. 2019. Biological management of southern blight of chili by Penicillium oxalicum and leaves of Eucalyptus citriodora. Int. J. Agr. Biol., 23, 93-102.

76. Jewell M.C., Campbell B.C, Godwin I.D. 2010. Transgenic plants for abiotic stress resistance. In: Kole C., Michler C.H., Abbott A.G., Hall T.C. (eds) Transgenic crop plants. Springer, Berlin, Heidelberg, 67-132.

77. Jiang S., Zhang D., Wang L., Pan J., Liu Y., Kong X., Li D. 2013. A maize calcium-dependent protein kinase gene, $\mathrm{ZmCPK} 4$, positively regulated abscisic acid signaling and enhanced drought stress tolerance in transgenic Arabidopsis. Plant Physiol. Biochem., $71,112-120$.

78. Jing Y.X., Yan J.L., He H.D., Yang D.J., Xiao L., Zhong T., Yuan M., Cai X.D., Li S.B. 2013. Characterization of Bacteria in the Rhizosphere Soils of Polygonum pubescens and Their Potential in Promoting Growth and $\mathrm{Cd}, \mathrm{Pb}, \mathrm{Zn}$ Uptake by Brassica napus. Int J Phytoremediat., 16(4), 321-333.

79. Julkowska M.M., Testerink C. 2015. Tuning plant signaling and growth to survive salt. Trends Plant Sci, 20, 586-594.

80. Kang S-M., Asaf S., Khan A.L., Lubna, Khan A., Mun B-G., Khan M.A., Gul H., Lee I-J. 2020. Complete Genome Sequence of Pseudomonas psychrotolerans CS51, a Plant Growth-Promoting Bacterium, Under Heavy Metal Stress Conditions. Microorganisms, 8(3), 382. doi:10.3390/ microorganisms 8030382 .

81. Kanwal S., Bano A., Malik R.N. 2015. Effects of arbuscular mycorrhizal fungi on metals uptake, physiological and biochemical response of Medicago sativa L. with increasing $\mathrm{Zn}$ and $\mathrm{Cd}$ concentrations in soil. Am. J. Plant Sci., 6, 2906-2923.

82. Karthik C., Elangovan N., Kumar T.S., Govindharaju S., Barathi S., Oves M., Arulselvi P.I. 2017. Characterization of multifarious plant growth promoting traits of rhizobacterial strain AR6 under Chromium (VI) stress. Microbiol. Res, 204, 65-71.

83. Karlidag H., Yildirim E., Turan M., Pehluvan M., Donmez F. 2013. Plant growth-promoting rhizobacteria mitigate deleterious effects of salt stress on strawberry plants (Fragaria $x$ ananassa). HortScience, 48(5), 563-567

84. Karlidag H., Esitken A., Turan M., Sahin F. 2007. Effects of root inoculation of plant growth promoting rhizobacteria (PGPR) on yield, growth and nutrient element contents of leaves of apple. Sci Hortic, 114(1), 16-20.

85. Kasim W.A., Gaafar R.M., Abou-Ali R.M., Omar M.N., Hewait H.M. 2016. Effect of biofilm forming plant growth promoting rhizobacteria on salinity tolerance in barley. Ann. Agric. Sci., 61, 217-227.

86. Kaur G., Reddy M.S. 2016. Improvement of crop yield by phosphate-solubilizing Aspergillus species in organic farming. Arch. Agron. Soil Sci., 63(1), 24-34.

87. Kaur G.,Asthir B. 2016. Molecular responses to drought stress in plants. Biol Plantarum, 61(2), 201-209.

88. Khade S.W., Rodrigues B.F. 2009. Applications of arbuscular mycorrhizal fungi in agroecosystems. Review. Trop Subtropical Agroecosyst, 10, 337-354.

89. Khan N., Zandi P., Ali S., Mehmood A., Adnan Shahid M., Yang J. 2018. Impact of Salicylic Acid and PGPR on the Drought Tolerance and Phytoremediation Potential of Helianthus annus. Front. Microbiol., 9, 2507. doi: 10.3389/fmicb.2018.02507.

90. Khan N., Bano A. 2016. Modulation of phytoremediation and plant growth by the treatment with PGPR, Ag nanoparticle and untreated municipal wastewater. Int J Phytoremediat, 18(12), 1258-1269.

91. Khan A.L., Hamayun M., Ahmad N. Waqas M., Kang S-M., Kim Y-H., Lee I-J. 2011a. Exophiala sp. LHL08 reprograms Cucumis sativus to higher growth under abiotic stresses. Physiol Plant, 143, 329-343.

92. Kotak S., Larkindale J., Lee U., von Koskull-Döring P., Vierling E., Scharf K-D. 2007. Complexity of 
the heat stress response in plants. Curr. Opin. Plant Biol., 10(3), 310-316.

93. Krishnamoorthy R., Kim K., Subramanian P., Senthilkumar M., Amanda R., Sa T. 2016. Arbuscular mycorrhizal fungi and associated bacteria isolated from salt-affected soil enhances the tolerance of maize to salinity in coastal reclamation soil. Agric Ecosyst Environ, 231, 233-239.

94. Kuan K.B., Othman R., Abdul R.K, Shamsuddin Z.H. 2016. Plant Growth-Promoting Rhizobacteria Inoculation to Enhance Vegetative Growth, Nitrogen Fixation and Nitrogen Remobilisation of Maize under Greenhouse Conditions. PLoS ONE 11(3), e0152478. doi:10.1371/journal.pone.0152478

95. Kumar A., Verma J.P. 2018. Does plant Microbe interaction confer stress tolerance in plants: A review? Microbiol. Res., 207, 41-52.

96. Kushwaha P., Kashyap P.L., Kuppusamy P. 2020. Microbes for Cold Stress Resistance in Plants: Mechanism, Opportunities, and Challenges. Rhizosphere Biology, 269-292.

97. Lal S., Tabacchioni S., Chiarini L. 2016. New Insights in Plant-Associated Paenibacillus Species: Biocontrol and Plant Growth-Promoting Activity. In: Islam M., Rahman M., Pandey P., Jha C., Aeron A. (eds) Bacilli and Agrobiotechnology. Springer, Cham, 237-279.

98. Lata R., Chowdhury S., Gond S.K., White Jr J.F. 2018. Induction of abiotic stress tolerance in plants by endophytic microbes. Lett. Appl. Microbiol., 66 (4), 268-276.

99. Lata R., Gond S.K. 2019. Plant growth-promoting microbes for abiotic stress tolerance in plants. Role of Plant Growth Promoting Microorganisms in Sustainable Agriculture and Nanotechnology, 89-105.

100. Lata C., Prasad M. 2011. The role of DREBs in the regulation of abiotic stress responses in plants. $\mathrm{J}$. Exp. Bot., 62, 4731-4748.

101. Latef A.A.H.A., Chaoxing H. 2011. Arbuscular mycorrhizal influence on growth, photosynthetic pigments, osmotic adjustment and oxidative stress in tomato plants subjected to low temperature stress. Acta Physiol Plant, 33, 1217-1225.

102. Lakshmanan V., Selvaraj G., Bais H.P. 2014. Functional soil microbiome: below ground solutions to an aboveground problem. Plant Physiol, 66, 689-700.

103. Lavakush Y.J., Verma J.P., Jaiswal D.K., Kumar A. 2014. Evaluation of PGPR and different concentration of phosphorus level on plant growth, yield and nutrient content of rice (Oryza sativa). Ecol. Eng., 62, 123-128.

104. Lee B.D., Dutta S., Ryu H., Yoo S-J., Suh D-S., Park K. 2015. Induction of systemic resistance in Panax ginseng against Phytophthora cactorum by native Bacillus amyloliquefaciens HK34. J. Ginseng Res., 39(3), 213-220.
105. Leifheit E.F., Verbruggen E., Rillig M.C. 2015. Arbuscular mycorrhizal fungi reduce decomposition of woody plant litter while increasing soil aggregation. Soil Biol Biochem, 8, 323-328.

106. Liu Z.L., Li Y-J., Hou H-Y., Zhu X-C., Rai V., He $X-Y .$, Tian, C-J. 2013. Differences in the arbuscular mycorrhizal fungi-improved rice resistance to low temperature at two N levels: Aspects of $\mathrm{N}$ and $\mathrm{C}$ metabolism on the plant side. Plant Physiol. Biochem., 71, 87-95.

107. Liu D., Lian B., Dong H. 2012. Isolation of Paenibacillus sp. and Assessment of Its Potential for Enhancing Mineral Weathering. Geomicrobiol. J., 29, 413-421.

108. Ludwig-Müller J. 2010. Hormonal responses in host plants triggered by arbuscular mycorrhizal fungi. In: Arbuscular mycorrhizas: Physiology and function (eds). Koltai H., Kapulnik Y. Dordrecht: Springer, 169-190.

109. Ma X.K., Ding N., Peterson E.C., Daugulis A.J. 2016a. Heavy metals species affect fungal-bacterial synergism during the bioremediation of fluoranthene. Appl.Microbiol. Biotechnol., 100, 7741-7750.

110. Ma Y., Rajkumar, M., Zhang, C., Freitas, H., 2016b. Beneficial role of bacterial endophytes in heavy metal phytoremediation. J. Environ. Manage, 174, 14-25.

111. Ma Y., Rajkumar M., Rocha I., Oliveira R.S., Freitas H. 2015. Serpentine bacteria influence metal translocation and bioconcentration of Brassica juncea and Ricinus communis grown in multimetal polluted soils. Front Plant Sci, 5, 757. doi: 10.3389/fpls.2014.00757.

112. Mani D., Kumar C., Patel N.K. 2016. Integrated micro-biochemical approach for phytoremediation of cadmium and lead contaminated soils using Gladiolus grandiflorus L. cut flower. Ecotoxicol. Environ. Saf., 124, 435-446.

113. Mathur S., Sharma M.P., Jajoo A. 2018. Improved photosynthetic efficacy of maize (Zea mays) plants with arbuscular mycorrhizal fungi (AMF) under high temperature stress. J. Photochem. Photobiol., 180, 149-154.

114. Meena H., Ahmed M.A., Prakash P. 2015. Amelioration of heat stress in wheat, Triticum aestivum by PGPR (Pseudomonas aeruginosa strain 2CpS1). Biosci. Biotech. Res. Comm., 8(2), 171-174.

115. Mena-Violante H.G., Ocampo-Jimenez O., Dendooven, L., Martinez-Soto G., Gonzalez-Castafeda J., Davies F.T., Olalde-Portugal V. 2006. Arbuscular mycorrhizal fungi enhance fruit growth and quality of chile ancho Capsicum annuum L. cv San Luis plants exposed to drought. Mycorrhiza, 16, 261-267.

116. Mendes R., Garbeva P., Raaijmakers J.M. 2013. The rhizosphere microbiome: significance of plant 
beneficial, plant pathogenic and human pathogenic microorganisms. FEMS Microbiol Rev, 37, 634-663.

117. Mikiciuk G., Sas-Paszt L., Mikiciuk M., Derkowska E., Trzcinski P., Ptak P., Chylewska U., Statkiewicz M., Lisek A. 2019a. Physiological Response of Three Grapevine Cultivars Grown in North-Western Poland to Mycorrhizal Fungi. S Afr J Enol Vitic, 40(1), 1-14.

118. Mikiciuk G., Sas-Paszt L., Mikiciuk M., Derkowska E., Trzciński P., Głuszek, S., LisekA., Wera-Bryl S., Rudnicka, J. 2019b. Mycorrhizal frequency, physiological parameters, and yield of strawberry plants inoculated with endomycorrhizal fungi and rhizosphere bacteria. Mycorrhiza, 29, 489-501.

119. Mimmo T., Pii Y., Valentinuzzi F., Astolfi S., Lehto N., Robinson B., Brunetto G., Terzano R., Cesco S. 2018. Nutrient availability in the rhizosphere: a review. Acta Hortic., 1217, 13-28.

120. Miransari M. 2017. Arbuscular mycorrhizal fungi and heavy metal tolerance in plants. In: Arbuscular mycorrhizas and stress tolerance of plants. (eds) Wu Q.S. Singapore: Springer Nature, 174-161.

121. Mishra J., Singh R., Arora N.K. 2017. Plant GrowthPromoting Microbes: Diverse Roles in Agriculture and Environmental Sustainability. In: Kumar V., Kumar M., Sharma S., Prasad R. (eds) Probiotics and Plant Health. Springer, Singapore, 71-111.

122. Moradtalab N., Roghieh H., Nasser A., Tobias E.H., Günter N. 2019. Silicon and the association with an arbuscular-mycorrhizal fungus ( $R h i$ zophagus clarus) mitigate the adverse effects of drought stress on strawberry. Agronomy, 9, 41. doi: 10.3389/fpls.2019.01068.

123. Mushtaq S., Nasim G., Khokhar I., Mukhtar I. 2012. Effects of Penicillium extracts on germination vigour in subsequent seedling growth of tomato (Solanum lycopersicum L.) Arch Phytopathol Plant Protect, 45, 932-937.

124. Nadeem S.M., Ahmad M., Zahir Z.A., Javaid A., Ashraf M. 2014. The role of mycorrhizae and plant growth promoting rhizobacteria (PGPR) in improving crop productivity under stressful environments. Biotechnol Adv., 32(2), 429-448.

125. Naseem H., Bano A. 2014. Role of plant growthpromoting rhizobacteria and their exopolysaccharide in drought tolerance of maize. J. Plant Interaction, 9, 689-701.

126. Naveed M., Hussain M.B., Zahir Z.A., Mitter B., Sessitsch A. 2014. Drought stress amelioration in wheat through inoculation with Burkholderia phytofirmans strain PsJN. Plant Growth Regul. 73(2), 121-131.

127. Naznin H.A., Kiyohara D., Kimura M., Miyazawa M., Shimizu M., Hyakumachi M. 2014. Systemic resistance induced by volatile organic compounds emitted by plant growth promoting fungi in Arabidopsis thaliana. PLoS One, 9(1), e86882. doi: 10.1371/journal.pone.0086882.

128. Nguyen T.D., Cavagnaro T.R. Watts-Williams S.J. 2019. The effects of soil phosphorus and zinc availability on plant responses to mycorrhizal fungi: a physiological and molecular assessment. Sci Rep, 9, 14880. https://doi.org/10.1038/ s41598-019-51369-5.

129. Oteino N., Lally R.D., Kiwanuka S., Lloyd A. Ryan D., Germaine K.J., Dowling D.N. 2015. Plant Growth Promotion Induced by Phosphate Solubilizing Endophytic Pseudomonas Isolates. Front. Microbiol., 6, 745. doi: 10.3389/ fmicb.2015.00745.

130. Patel S., Sayyed R.Z., Saraf M. 2016. Bacterial Determinants and Plant Defense Induction: Their Role as Biocontrol Agents in Sustainable Agriculture. In: Hakeem K., Akhtar M. (eds) Plant, Soil and Microbes. Springer, Cham, 187-204.

131. Pedranzani H., Tavecchio N., Gutiérrez M., Garbero M., Porcel R., Ruiz-Lozano J.M. 2015. Differential effects of cold stress on the antioxidant response of mycorrhizal and non-mycorrhizal Jatropha curcas (L.) plants. J Agric Sci, 7, 35. doi:10.5539/jas.v7n8p35.

132. Pérez-Jaramillo J.E., Mendes R., Raaijmakers J.M. 2015. Impact of plant domestication on rhizosphere microbiome assembly and functions. Plant Mol Biol, 90, 635-644.

133. Philippot L., Raaijmakers J.M., Lemanceau P., van der Putten W.H. 2013. Going back to the roots: the microbial ecology of the rhizosphere. Nat Rev Microbiol, 11, 789-799.

134. Pieterse C.M.J., Zamioudis C., Berendsen R.L., Weller D.M., Van Wees S.C.M., Bakker P.A.H.M. 2014. Induced systemic resistance by beneficial microbes. Annu Rev Phytopathol, 52, 347-375.

135. Porcel R., Redondo-Gómez S., Mateos-Naranjo E., Aroca R., Garcia R., Ruiz-Lozano J.M. 2015. Arbuscular mycorrhizal symbiosis ameliorates the optimum quantum yield of photosystem II and reduces non-photochemical quenching in rice plants subjected to salt stress. J Plant Physiol, 185, 75-83.

136. Porcel R., Zamarreño Á., García-Mina J., Aroca, R. 2014. Involvement of plant endogenous ABA in Bacillus megaterium PGPR activity in tomato plants. BMC Plant Biology, 14(1), 36. https://doi. org/10.1186/1471-2229-14-36.

137. Qin Y., Shang Q., Zhang Y., Li P., Chai Y. 2017. Bacillus amyloliquefaciens L-S60 Reforms the Rhizosphere Bacterial Community and Improves Growth Conditions in Cucumber Plug Seedling. Front Microbiol. 8, 2620. doi: 10.3389/fmicb.2017.02620.

138. Qu A-L., Ding Y-F., Jiang Q., Zhu C. 2013. Molecular mechanisms of the plant heat stress response. Biochem. Biophys. Res. Commun., 432(2), 203-207. 
139. Rana A., Saharan B., Nain L., Prasanna R., Shivay Y.S. 2012. Enhancing micronutrientuptake and yield of wheat through bacterial PGPR consortia. Soil Sci. Plant Nutr., 58, 573-582.

140. Rathore P. 2015. A Review on Approaches to Develop Plant Growth Promoting Rhizobacteria Int. J. Recent. Sci. Res, 5(2), 403-407.

141. Rollon R.J.C., Galleros J.E.V., Galos G.R., Villasica L.J.D., Garcia C.M. 2017. Growth and nutrient uptake of Paraserianthes falcataria (L.) as affected by carbonized rice hull and arbuscular mycorrhizal fungi grown in an artificially copper contaminated soil. AAB Bioflux, 9(2), 57-67.

142. Ruiz-Lozano J.M., Aroca R., Zamarreño Á.M., Molina S., Andreo-Jiménez B., Porcel R., García-Mina J.M., Ruyter-Spira C., López-Ráez J.A. 2015. Arbuscular mycorrhizal symbiosis induces strigolactone biosynthesis under drought and improves drought tolerance in lettuce and tomato. Plant Cell Environ., 39(2), 441-452.

143. Sánchez-López A.M., Bahaji A., De Diego N., Baslam M., Li J., Muñoz F.J., Almagro G., GarcíaGómez P., Ameztoy K., Ricarte-Bermejo A., Novák O., Humplík J.F., Spíchal L., Doležal K., Ciordia S., Mena M.C., Navajas R., Baroja-Fernández E., Pozueta-Romero J. 2016. Arabidopsis responds to Alternaria alternata volatiles by triggering plastid phosphoglucose isomerase-independent mechanisms. Plant Physiol, 172, 989-2001.

144. Sara O., Ennajeh M., Zrig A., Gianinazzi, S., Khemira H. 2018. Estimating the contribution of arbuscular mycorrhizal fungi to drought tolerance of potted olive trees (Olea europaea). Acta Physiol. Plant., 40, 1-81.

145. Sarma R.K., Saikia R. 2013. Alleviation of drought stress in mung bean by strain Pseudomonas aeruginosa GGRJ21. Plant Soil, 377(1-2), 111-126.

146. Sas-Paszt L., Sumorok B., Malusa E., Głuszek S., Derkowska E. 2011. The influence of bioproducts on root growth and mycorrhizal occurrence in the rhizosphere of strawberry plants 'Elsanta'. J Fruit Ornam Plant Res, 19(1), 13-33.

147. Seema K., Mehta K., Singh N. 2018. Studies on the effect of plant growth promoting rhizobacteria (PGPR) on growth, physiological parameters, yield and fruit of strawberry cv. Chandler. J Pharmacogn Phytochem, 7(2), 383-387.

148. Selvakumar G., Joshi P., Suyal P., Mishra P.K., Joshi G.K., Bisht J.K., Bhatt J.C., Gupta H.S. 2011. Pseudomonas lurida M2RH3 (MTCC 9245), a psychrotolerant bacterium from the Uttarakhand Himalayas, solubilizes phosphate and promotes wheat seedling growth. World J Microbiol Biotechnol, 27(5), 1129-1135.

149. Seneviratne M., Gunaratne S., Bandara T., Weerasundara L., Rajakaruna N., Seneviratne G.,
Vithanage M. 2016. Plant growth promotion by Bradyrhizobium japonicum under heavy metal stress. S. Afr. J. Bot, 105, 19-24.

150. Sharma P., Kumawat K.C., Kaur S. 2016. Plant Growth Promoting Rhizobacteria in Nutrient Enrichment: Current Perspectives. In: Singh U., Praharaj C., Singh S., Singh N. (eds) Biofortification of Food Crops. Springer, New Delhi, 263-289.

151. Sharma P., Kharkwal A.C., Abdin M.Z., Varma A. 2016. Piriformospora indica-mediated salinity tolerance in Aloe vera plantlets. Symbiosis, 72(2), 103-115.

152. Shen H., Christie P., Li X. 2006. Uptake of zinc, cadmium and phosphorus by arbuscular mycorrhizal maize (Zea mays L.) from a low available phosphorus calcareous soil spiked with zinc and cadmium. Environ. Geochem. Health, 28, 111. doi: 10.1007/s10653-005-9020-2.

153. Shukla P.S., Agarwal P.K. Jha B. 2012. Improved Salinity Tolerance of Arachis hypogaea (L.) by the Interaction of Halotolerant Plant-Growth-Promoting Rhizobacteria. J Plant Growth Regul, 31, 195-206.

154. Shrivastava P., Kumar R. 2015. Soil salinity: a serious environmental issue and plant growth promoting bacteria as one of the tools for its alleviation Saudi J. Biol. Sci., 123-131.

155. Singh S.K., Singh P.P., Gupta A., Singh A.K., Keshri J. 2019. Tolerance of Heavy Metal Toxicity Using PGPR Strains of Pseudomonas Species. PGPR Amelioration in Sustainable Agriculture, 239-252.

156. Smith S.E., Read D.J. 2008. Mycorrhizal Symbiosis. 3rd Edition, Academic Press, London.

157. Son J-S., Sumayo M., Hwang Y-J., Kim B-S., Ghim S-Y. 2014. Screening of plant growth-promoting rhizobacteria as elicitor of systemic resistance against gray leaf spot disease in pepper. Appl. Soil Ecol., 73, 1-8.

158. Spence C., Bais H. 2015. The role of plant growth regulators as chemical signals in plant-microbe interactions: a double edged sword. Curr. Opin. Plant Biol., 27, 52-58.

159. Sridhar B.S. 2012. Review: Nitrogen Fixing Microorganisms. Int. J. Microbiol, 3(1), 46-52.

160. Suarez C., Cardinale M., Ratering S., Steffens D., Jung S., Montoya A.M.Z., Geissler-Plaum R., Schnell S. 2015. Plant growth-promoting effects of Hartmannibacter diazotrophicus on summer barley (Hordeum vulgare L.) under salt stress. Appl. Soil Ecol., 95, 23-30.

161. Talaat N.B., Shawky B.T. 2014. Protective effects of arbuscular mycorrhizal fungi on wheat (Triticum aestivum L.) plants exposed to salinity. Environ. Exp. Bot., 98, 20-31.

162. Ting A.S.Y., Mah S.W., Tee C.S. 2010. Identification of volatile metabolites from fungal endophytes with biocontrol potential towards Fusarium 
oxysporum f. sp. cubense Race 4. Am J Agric Biol Sci, 5(2), 177-182.

163. Tiwari S., Lata C., Chauhan P.S., Nautiyal C.S. 2015. Pseudomonas putida attunes morphophysiological, biochemical and molecular responses in Cicer arietinum L. during drought stress and recovery. Plant Physiol. Biochem., 99, 108-117.

164. Turan M., Gulluce M., Cakmak R., Sahin F. 2013. Effect of plant growth promoting Rhizobacteria strain on freezing injury and antioxidant enzyme activity of wheat and barley. J Plant Nutr, 36, 731-748.

165. Upadhyay S.K, Singh J.S, Saxena A.K, Singh D.P. 2011. Impact of PGPB inoculation on growth and antioxidants status of wheat plant under saline condition. Plant Biol, 14, 605-611.

166. Vázquez-de-Aldana B.R., Zabalgogeazcoa I., García-Ciudad A., García-Criado B. 2013. An Epichloë endophyte affects the competitive ability of Festuca rubra against other grassland species. Plant Soil, 362, 201-213.

167. Vardharajula S., Ali S.Z., Grover M., Reddy G., Bandi V. 2011. Drought-tolerant plant growth promoting Bacillus spp.: effecton growth, osmolytes, and antioxidant status of maize under drought stress. J. Plant Interact., 6(1), 1-14.

168. Vu T.T., Hauschild R., Sikora R.A. 2006. Fusarium oxysporum endophytes induced systemic resistance against Radopholus similis on banana. Nematology, 8, 847-852.

169. Waghunde R.R., Shelake R.M., Shinde M.S., Hayashi H. 2017. Endophyte microbes: a weapon for plant health management. In: Microorganisms for green revolution. Springer, Singapore, 303-325.

170. Wahid A., Gelani S., Ashraf M., Foolad M. 2007. Heat tolerance in plants: An overview. Environ Exp Bot, 61(3), 199-223.

171. Wang Y., Jing H., Gao Y. 2012. Arbuscular mycorrhizal colonization alters subcellular distribution and chemical forms of cadmium in Medicago sativa L. and resists cadmium toxicity. PLoS One 7,3161-3164. doi: 10.1371/journal.pone.0048669

172. Wang C-J., Yang W., Wang C., Gu C., Niu D-D., Liu H-X., Wang Y-P., Guo J-H. 2012. Induction of Drought Tolerance in Cucumber Plants by a Consortium of Three Plant Growth Promoting Rhizobacterium Strains. PLoS ONE, 7(12), e52565. doi:10.1371/journal.pone.0052565.

173. Yadav S.K., Singh S., Singh H.B., Sarma B.K. 2017. Compatible Rhizosphere-Competent microbial consortium adds value to the nutritional quality in Edible parts of Chickpea. J. Agr. Food Chem., 65, 6122-6130.

174. Yamagiwa Y., Toyoda K., Inagaki Y., Ichinose Y., Hyakumachi M., Shiraishi T. 2011. Talaromyces wortmannii FS2 emits $\beta$-caryophyllene, which promotes plant growth and induces resistance. J
Gen Plant Pathol, 77, 336-341.

175. Yeasmin R., Bonser S.P., Motoki S., Nishihara E. 2019. Arbuscular Mycorrhiza Influences Growth and Nutrient Uptake of Asparagus (Asparagus officinalis L.) under Heat Stress, HortScience horts, 54(5), 846-850.

176. Yooyongwech S., Samphumphuang T., Tisarum R., Theerawitaya C., Chaum S. 2016. Arbuscular mycorrhizal fungi (AMF) improved water deficit tolerance in two different sweet potato genotypes involves osmotic adjustments via soluble sugar and free proline. Sci Hort. 198, 107-117.

177. Zandalinas S.I., Mittler R., Balfagón D., Arbona V., Gómez-Cadenas A. 2018. Plant adaptations to the combination of drought and high temperatures. Physiol Plant 162(1), 2-12.

178. Zavala-González E.A., Escudero N., Lopez-Moya F., Aranda-Martinez A., Exposito A., Ricaño-Rodríguez J., Naranjo-Ortiz M.A., Ramírez-Lepe M., Lopez-Llorca L.V. 2015. Some isolates of the nematophagous fungus Pochonia chlamydosporia promote root growth and reduce flowering time in tomato. Ann Appl Biol, 166, 472-483.

179. Zhang S., Gan Y., Xu B. 2016. Application of Plant-Growth-Promoting Fungi Trichoderma longibrachiatum T6 Enhances Tolerance of Wheat to Salt Stress Through Improvement of Antioxidative Defense System and Gene Expression. Front Plant Sci, 7, 1405. doi: 10.3389/fpls.2016.01405.

180. Zhang N., Wang D.D., Liu Y.P., Li S.Q., Shen Q., Zhang R.F. 2014. Effects of differentplant root exudates and their organic acid components on chemotaxis, biofilm formation and colonization by beneficial rhizosphere - associated bacterial strains. Plant Soil, 374, 689-700.

181. Zhao R., Guo W., Bi N., Guo J., Wang L., Zhao J., Zhang J. 2015. Arbuscular mycorrhizal fungi affect the growth, nutrient uptake and water status of maize (Zea mays L.) grown in two types of coal mine spoils under drought stress. Appl. Soil Ecol., 88, 41-49.

182. Zhu X.C., Song F.B., Xu H.W. 2010b. Effects of arbuscular mycorrhizal fungi on photosynthetic characteristics of maize under low temperature stress. Acta Ecol. Sin., 21, 470-475.

183. Zhuang K., Kong F., Zhang S., Meng C., Yang M., Liu Z., Wang Y., Ma N., Meng Q. 2019. Whirly enhances tolerance to chilling stress in tomato via protection of photosystem II and regulation of starch degradation. New Phytol, 221, 1998-2012.

184. Zubair M., Hanif A., Farzand A., Sheikh T.M.M., Khan A.R., Suleman M., Ayaz M., Gao X. 2019. Genetic Screening and Expression Analysis of Psychrophilic Bacillus spp. Reveal Their Potential to Alleviate Cold Stress and Modulate Phytohormones in Wheat. Microorganisms, 7, 337. doi: 10.3390/microorganisms7090337. 